\title{
Metropolis Aşağı Hamam Palaestra'da (Han Yıkığı) Ele Geçen Doğu Sigillata B Grubu Seramikleri
}

\author{
Eastern Sigillata B Group Pottery from The Lower Bath Palaestra (Han Yıkığı) of Metropolis
}

\section{Volkan YILDIZ*}

Öz: Bu çalışmada, Metropolis antik kentinin önemli yapılarından birisi olan Aşağı Hamam Palaestra'da (Han Yıkığı) gerçekleştirilen kazılar sonucunda ele geçen Doğu Sigillata B grubu seramikleri değerlendirilmiștir. Yapıda bulunan seramiklerin değerlendirilmesi sonucunda Doğu Sigillataları arasında en yoğun bulunan grubun 127 örnekle Doğu Sigillata B grubu seramikleri olduğu tespit edilmiştir. Bu gruba giren seramikler J. Hayes' in tipolojisinden hareketle DSB 1 ve DSB 2 olmak üzere iki alt gruba ayrılmıştır. $\mathrm{Bu}$ kadar zengin bir buluntu grubu beraberinde 17 formdan oluşan geniş bir form repertuvarının oluşmasını sağlamıştır. Bu geniş form çeşitliliği bazı formların varyasyonlarının ve imitasyonlarının varlığını göstermesi açısında da oldukça önemlidir. Bu 17 formdan Mtr Aşağı Hamam Palaestra Form 1- 8 arası DSB 1 grubunda ele al1nırken, Mtr Așağı Hamam Palaestra Form 9-17 arası ise DSB 2 grubunda değerlendirilmiștir. Așağı Hamam Palaestra'da ele geçen Doğu Sigillata B grubu örnekleri arasında en erken örnek MS I. yüzyılın ilk yarısına tarihlenmektedir. Bu grubagiren en geçörnek ise MS III. yüzyıla aittir. Yapıda bu grubun en yoğun görüldüğü tarih ise MS I. yüzyıldır. Elde edilen bu veriler sonucunda, Metropolis' in, bu grubun üretim yerleri arasında olduğu kabul edilen Tralleis ve Ephesos gibi kentlerle söz konusu tarih aralığında güçlü ticari ilişkilerinin olduğu görülmektedir.

Anahtar Kelimeler: Metropolis • Ionia • Aşağı Hamam Palaestra • Roma Seramiği • Doğu Sigillataları • Doğu Sigillata $\mathrm{B}$
Abstract: In this research, the Eastern Sigillata B finds which were found during the excavations carried out in The Lower Bath Palaestra (Han Yıkığı) of Metropolis are presented. The Lower Bath Palaestra forms one of the important structures of the ancient city of Metropolis. Among the Eastern Sigillata finds from The Lower Bath Palaestra, the richest group, is the Eastern Sigillata B group with 127 examples. These finds are divided into two subgroups, ESB 1 and ESB 2, dependant on the typology of J. Hayes. Such a rich group of finds provides to a wide form repertoire, consisting of 17 forms. This form diversity is also important in observing the variations and the imitations of some forms. Among these 17 forms, Mtr Lower Bath Palaestra Form 1-8 are classified as ESB 1 and Mtr Lower Bath Palaestra Form 9-17 are classified as ESB 2. The earliest example of ESB from The Lower Bath Palaestra is dated to the first half of the $\mathrm{I}^{\text {st }}$ century A.D. The latest example is dated to the III ${ }^{\mathrm{rd}}$ century A.D. Finds from the $\mathrm{I}^{\text {st }}$ century A.D. are the most common ESB examples from the building. According to the information obtained through this research, it is safe to say that during this time period $\mathrm{I}^{\mathrm{st}}-\mathrm{III}^{\mathrm{rd}}$ century A.D. Metropolis had strong commercial relations with both Tralleis and Ephesus, among the production centres for this pottery group.

Keywords: Metropolis • Ionia $\bullet$ Lower Bath Palaestra • Roman Pottery • Eastern Sigillata • Eastern Sigillata B

* Dr. Öğr. Üyesi, Manisa Celal Bayar Üniversitesi, Fen-Edebiyat Fakültesi, Arkeoloji Bölümü, Manisa. (D) 0000-0002-1917-521X | yildiz.volkan@cbu.edu.tr Bu makale; 2016 yılında başlattı̆̆ımız ve halen devam etmekte olan "Metropolis Kazısı Hellenistik ve Roma Dönemleri Seramik Araştırmaları” projesi kapsamında hazırlanmışıı. Böyle bir çalışma için beni kazı ekibine dahil eden, malzemeyi çalışma aşamasında desteklerini esirgemeyen Metropolis Kazısı başkanı, Prof. Dr. Serdar AYBEK başta olmak üzere tüm kazı ekibine çok teşekkür eder, şükranlarımı sunarım. Son olarak, çalışmalarım sırasındaki yardımlarından dolayı Arş. Gör. Baykal BAŞDEMİR'e, arkeolog Esra SAĞUN’a ve arkeolog Gözdem GÜLER'e ne kadar teşekkür etsem azdır. 
Metropolis antik kenti, İzmir' in Torbalı ilçesinde, Yeniköy ve Özbey mahalleleri arasında bir tepede ve bu tepenin yamaçlarında kurulmuştur (bk. Fig. 1-2). Bazı antik kaynaklarda Ionia-Lydia sınırında gösterilen Metropolis çoğunlukla bir Ionia kenti olarak kabul edilmektedir ${ }^{1}$. Ayrıca kentin sikkelerinde görülen Ionia lejantı Metropolis' in bir Ionia kenti olarak tanımlanmasına olanak sağlamaktadır. Bulunduğu mevki açısından çağlar boyunca stratejik öneme sahip olan Metropolis, Küçük Menderes (Kaystros) havzasının batı ucunda, ovaya hâkim bir konumdadır. Ticaretten elde ettiği zenginlik ve ün, bu verimli ovada yetiștirilen mahsullerden kaynaklanmaktadır².

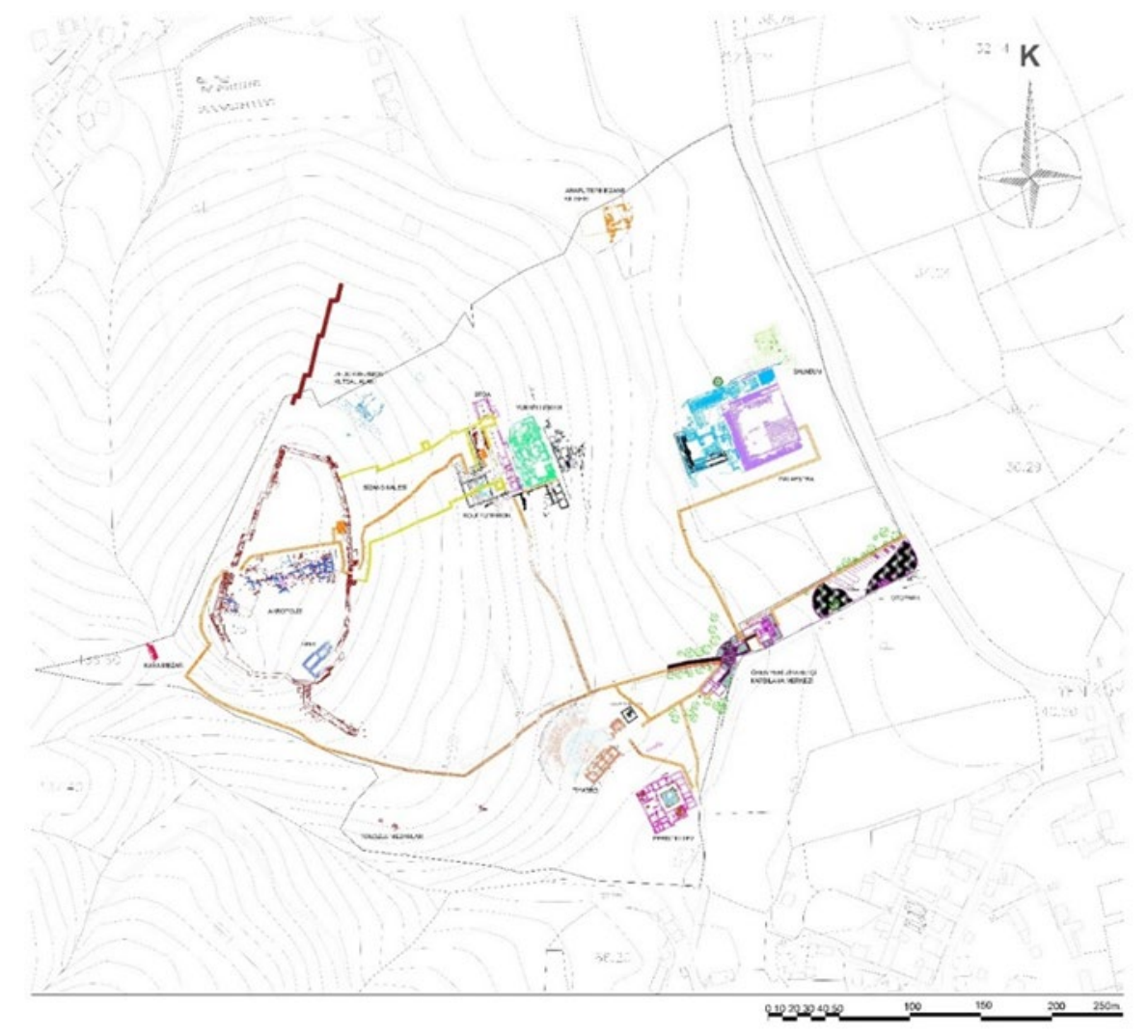

Fig. 1. Metropolis Kent Planı (Metropolis Kazı Arşivi)

Kentte, ilk kez 1989 yılında Prof. Dr. Recep Meriç başkanlığında başlayan sistemli arkeolojik kazı ve araştırmalar 2006 yılından itibaren ikinci dönem kazıları olarak Prof. Dr. Serdar Aybek başkanlığındaki bir ekip tarafından devam ettirilmektedir. Söz konusu arkeolojik kazılar sonucunda kentin MÖ VII. yüzyıl sonlarından Beylikler Dönemi'ne kadar uzanan süreçte zengin bir buluntu çeşitliliğine sahip olduğu anlaşılmıştır³. Bu makalenin konusunu oluşturan seramiklerin bulunduğu Aşağı Hamam Palaestra yapısı da geniş tarihsel süreç içerisindeki zengin buluntu ve yapı çeşitliliğinin bir parçasıdır. Bu yapı Metropolis’ in doğu yamacının ovayla birleștiği noktada yer almaktadır. Yapı halk arasında Han Yıkığı olarak adlandırılmaktadır. Kazılar başlamadan önce bile görülebilen duvar kalıntısı ve çevresini araştırmak için yapıda kazı çalışmaları 2003 yılında başlamıştır ${ }^{4}$. Söz konusu alanda 2003-

1 Aybek \& Arslan 2015, 29; 2020, 113; Aybek 2016, 109; 2018a, 9; 2018b, 294; Aybek \& Gülbay 2019, 241.

2 Aybek 2018b, 294.

3 Aybek 2016, 109.

4 Aybek 2016, 116. 
2006, 2009-2019 yıllarında aralıklarla kazılar gerçekleştirilmiştir ${ }^{5}$. Bu kazı çalışmaları sonucunda ortaya çıan büyük bir tonoz ve ısıtmayla bağlantılı hypocaust sistemine ait tubuli ve pillae parçaları, alandaki yapının imparatorluk tipi bir hamam olduğunu göstermiştir ${ }^{6}$. Farklı tarihlerde gerçekleştirilen kazılar sonucunda hamamın ana bölümlerini oluşturan tepidarium, caldarium, yıkanma havuzları, palaestra ve palaestra'yı çevreleyen geometrik mozaikli portikolar ortaya çıkarılmıştır. Portikolara ait arşitrav blokları üzerinde yer alan yazıt, yapının İmparator Antoninus Pius zamanında inşa edildiğini göstermektedir. Mimari olarak yapı, farklı dönemlerde değiş̧iklikler geçirmiştir. Elde edilen veriler sonucunda yapının 3 evreli olduğu saptanmıştır. İlk evrede frigidarium, tepidarium ve caldarium bölümlerinden oluşan küçük bir yapıdır. Yapıda değişikliğin ve büyütmenin asıl yapıldığı evre Antoninus Pius (MS 138-161) zamanında olmuştur. Yapının ikinci evresi olarak değerlendirilen bu dönemde yapıya yeni bir caldarium, servis koridorları, palaestra ve mozaikli portikolar eklenerek kapasitesi arttırılmıștır. Böylece yapı tipik imparatorluk sıralı tip hamam formunu kazanmıştır ${ }^{7}$ Yapının son evresi olan 3. evre MS IV. yüzyıl ve sonrası olarak yorumlanmıştır. Ancak hamamın bu evrede orijinal işleviyle kullanılıp kullanılmadığı kesin değildir. 3. evredeki duvar yapım teknikleri incelendiğinde mimari birimlerin onarım, hatta işlev değişiklikleri geçirdikleri görülmüştür. Ayrıca yine söz konusu alanda Doğu Roma İmparatorluk Dönemi pithosları ve su sistemleriyle desteklenen çeșitli atölyeler saptanmıştır

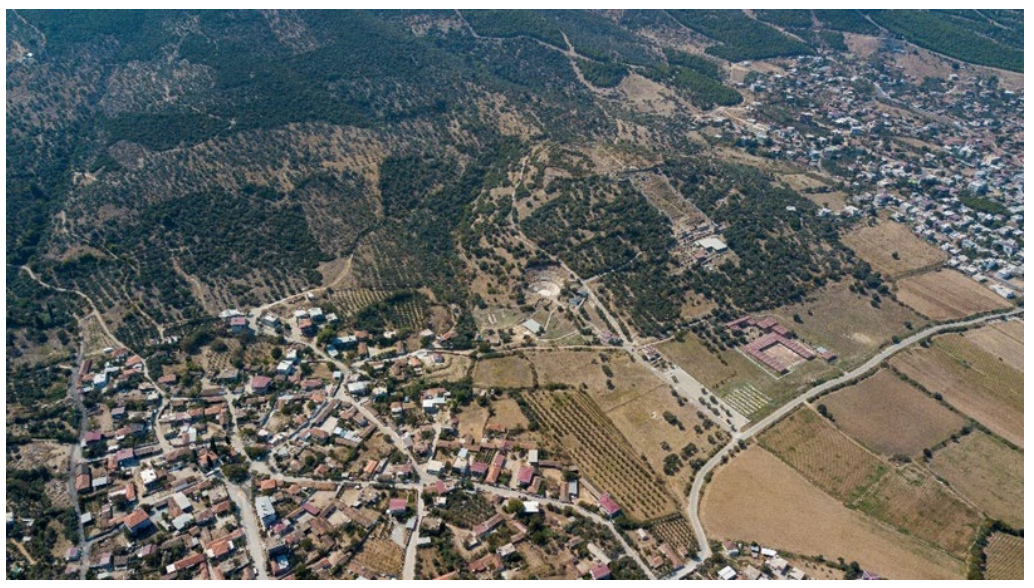

Fig. 2. Metropolis Hava Fotoğrafi (Metropolis Kazı Arşivi)

Aşağı Hamam Palaestra yapısında 2003-2006 ve 2009-2019 yılları arasında aralıklarla gerçekleştirilen kazılar sonucunda en yoğun bulunan seramik gruplarının başında Roma ve Geç Roma Dönemi kırmızı astarlı seramikleri gelmektedir. Yapıda bulunan kırmızı astarlı seramikler arasında Doğu Sigillataları A, B, Cgrubu'; (bk. Fig. 3) Geç Roma Kırmızı Astarlı Seramikleri arasında ise Ephesos Kırmızı Astarlı Seramikleri, Menderes Vadisi Kırmızı Astarlı Seramikleri, Phokaia Kırmızı Astarlı Seramikleri (Geç Roma C), Geç Roma D Seramikleri (Kıbrıs Kırmızı Astarlı Seramikleri) ve Afrika Kırmızı Astarlı Seramikleri bulunmaktadır (bk. Fig. 4).

5 Bu alanlarda yürütülen kazı çalışmaları hakkında detaylı bilgi için bk. Meriç et al. 2003, 137-147; 2005, 249-261; 2006, 243-253; Aybek et al. 2010, 166-181; 2011, 313-337; 2014, 325-347; 2015, 25-45; 2016, 439-457; 2019, 151-170.

6 Yapı ile detaylı bilgi için bk. Aybek 2014, 107-124; 2016, 109-124.

7 Aybek 2016, 117.

8 Aybek 2016, 118.

9 Buradan sonra Doğu Sigillata gruplarının "DSA", "DSB”, "DSC” ve DSD şeklinde kısaltması kullanılacaktır. 


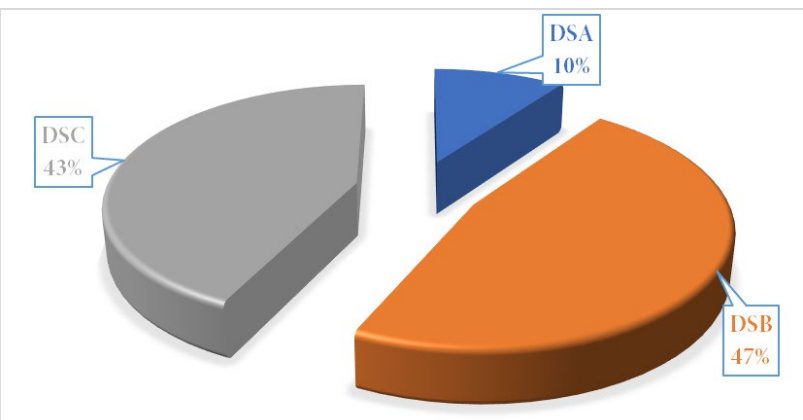

Fig. 3. Așağı Hamam Palaestra'da Bulunan Doğu Sigillatalarının Sayısal Dağılımı

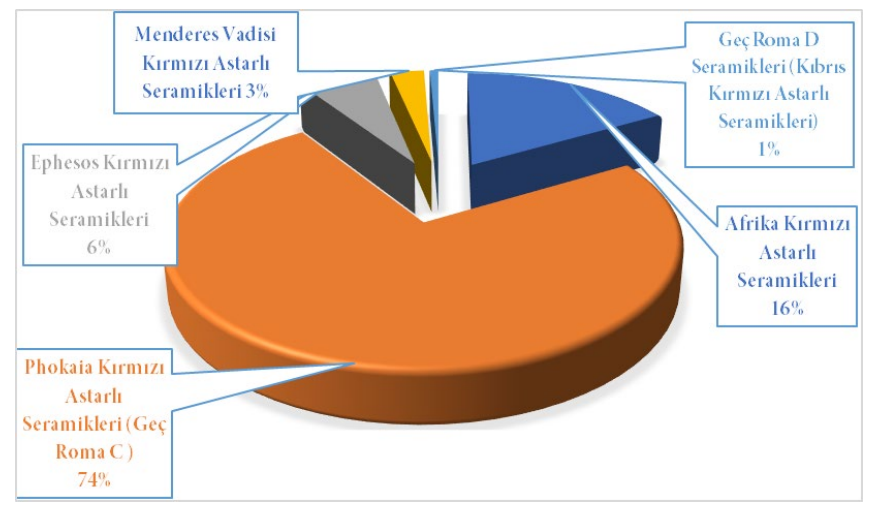

Fig. 4. Aşă̆ı Hamam Palaestra'da Bulunan Geç Roma Kırmızı Astarlı Seramiklerinin Sayısal Dağılımı

Bu makalenin amacı, Metropolis Aşağı Hamam Palaestra yapısında 2003-2006 ve 2009-2019 yılları arasında aralıklarla gerçekleştirilen kazılar sonucunda bulunan Doğu Sigillatası gruplarından DSB’leri değerlendirmektir. Çalışmada DSB grubundan 50 parça kataloglanmıştır. Grubun büyük çoğunluğu amorf durumundaki seramiklerden oluşmaktadır. Yapılan çalışmada seramikler form, hamur ve astar gruplarına göre de incelenmiş̦tir. Seramiklerin formları karşılaştırma yöntemi ile hamur ve astar özellikleri ise "Munsel Soil Color Charts" kataloğuna bakılarak saptanmıştır. Așağı Hamam Palaestra'da bulunan DSB'ler dolgu toprağından Hellenistik Dönem ve Roma Dönemi’ne ait farklı seramik grupları ve diğer buluntularla birlikte bulunmuştur. DSB'lerin dolgu toprağının içinde farklı buluntu gruplarıyla karışık bir şekilde bulunmasında yapının Metropolis'in doğu yamacının ovayla birleștiği noktada yer alması önemli bir etkendir. Bu açıdan bakıldığında bir tepenin ve yamacın üzerine kurulan kentte akıntı toprak yapıyı doldurmuştur. Dolayısıyla kontekstlerinin olmayışı, yapı genelinde stratigrafinin genel anlamda takip edilememesi nedeniyle tarihlendirmeler, analojik karşılaştırma örneklerine göre yapılmıştır. Bir başka ifadeyle yapı genelinde bulunan diğer buluntu gruplarından tarihlendirmede faydalanılamamıștır. Ayrıca kentin DSB üretim merkezleri olarak anılan kentlere çok yakın olması nedeniyle başta Ephesos, Tralleis ve Magnesia gibi kentlerde bulunan DSB örnekleri karşılaştırmada kullanılmıştır. Bu bağlamda bakıldığında ise yapıda bulunan DSB'lerin karşılaştırma ve tarihlenmesinde öncelikle komşu kentler ve daha sonra ise Batı Anadolu, Akdeniz ve Yunanistan'daki örnekler baz alınmıştır. Ayrıca J. Hayes'in bu konulardaki kapsamlı ve güncel yayınları analoji için tercih edilmiştir.

Metropolis Aşağı Hamam Palaestra'da bulunan DSB'ler 127 parçadır. Bu seramiklerden gövde parçaları, form takibi yapılamayan küçük boyutlu parçalar ve birbirinin tekrarı olan parçalar çalışma kapsamı dışında bırakılmıştır. 50 parça seramik Hayes' in tipolojisine bağlı kalarak gruplandırılmıștır. 
Gruplandırma sonucunda DSB 1 grubundan 8 form, DSB 2 grubundan ise 9 form saptanmıştır. DSB grubuna giren toplam 17 form mevcuttur (bk. Fig. 6). Bu sinıflandırmaya göre tabak ve kaseler ana kap türlerini oluşturmaktadır (bk. Fig. 5).

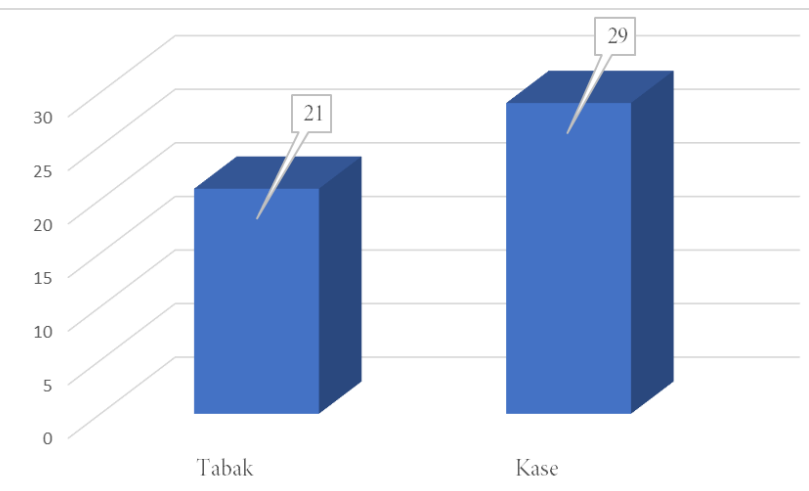

Fig. 5. Așağı Hamam Palaestra'daki DSB Formlarının Kap Türlerine Göre Sayısal Dağılımı

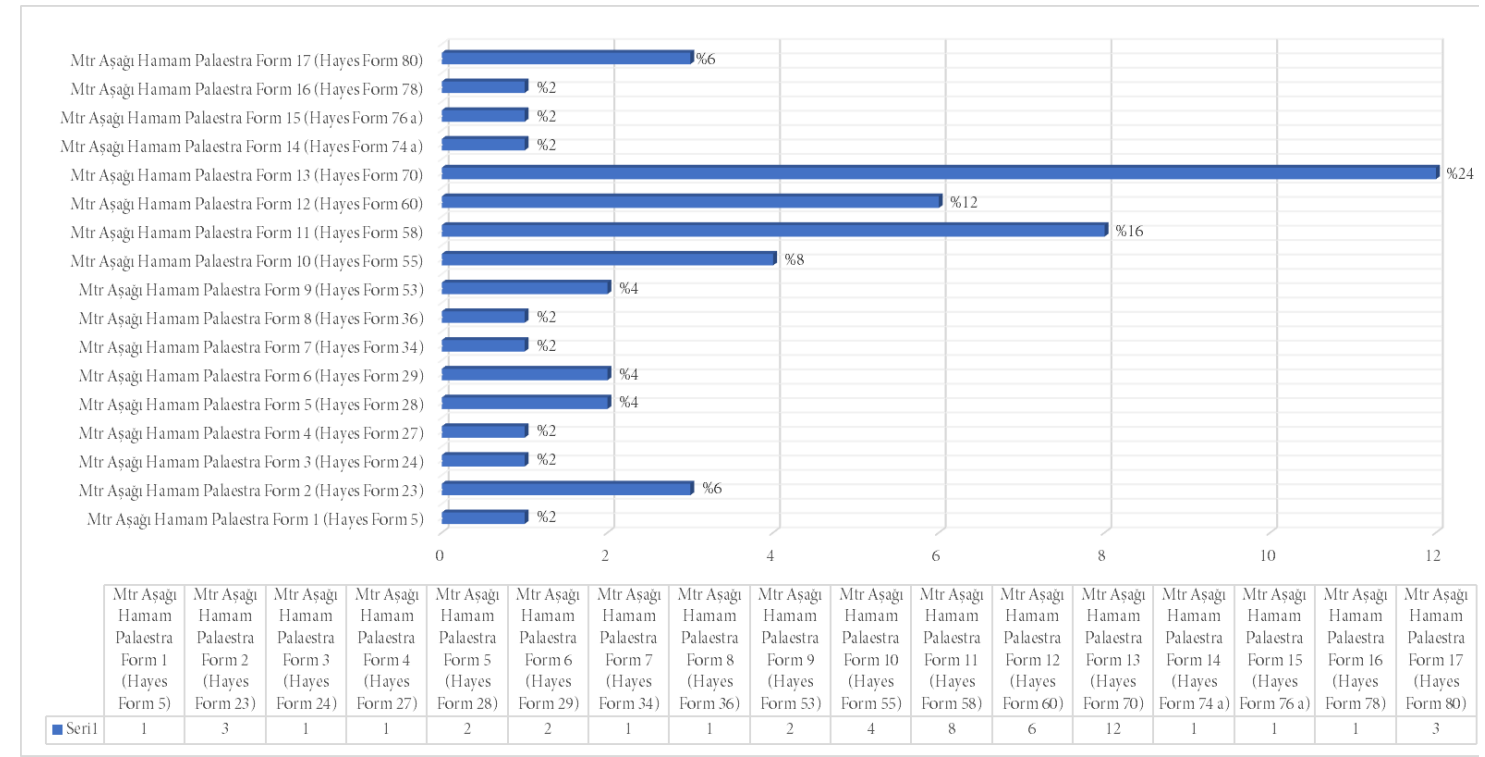

Fig. 6. Aşă̆ı̆ Hamam Palaestra'da Saptanan DSB Formları

Latince kökenli terra sigillata terimi seramik terminolojisinde, 19. yüzyıldan itibaren, topraktan yapılan kabartmalı ve bezemeli kap anlamına gelmektedir. Kelime karşılığında vurgulandığı üzere kırmızı veya kırmızımsı kahverengi astarlı ve kabartmalı seramikleri tanımlayan bu terim, aynı astar özelliklerine sahip, bezemesiz seramikleri de kapsamaktadır. Ayrıca başlangıçta İtalya kökenli parlak, nitelikli kırmızı astarlı batı seramikleri için kullanılan bu tanımlama, daha sonra doğuda üretilen kırmızı astarlı seramikler için de tercih edilmiştir ${ }^{10}$. Günlük kullanıma yönelik olan bu seramiklerin ilk ortaya çıkış yeri, Roma İmparatorluğu’nun doğusu olarak kabul edilir ${ }^{11}$. Daha önceleri buluntu yerine göre, örneğin "Samian Ware", "Pergamen Ware" veya "Çandarlı Ware" gibi adlandırılan bu seramikler, daha sonra hamur ve astar renklerine göre gruplandırılmışlardır ${ }^{12}$. Özelikle eski literatürde değerlen-

10 Uygun 2011, 3.

11 Korkut \& Ișin 2015, 220.

12 Uygun 2011, 3-4; Yıldız 2016, 255. 
dirilen bu üç tip, K. Kenyon'un yaptığı yeni bir sınıflandırma ile A, B, C grupları olarak adlandırılmış$\operatorname{tır}^{13}$. Günümüzde bu harflerle yapılan kodlama daha çok kabul görmüştür. Her grup birbirinden farklı bir kronolojik süreç içerisinde üretildiği gibi, birbirinden farklı formların kullanılmış olduğu da bilinmektedir. Ancak bazı kap formları her üç grup içerisinde olduğu gibi, diğer kırmızı astarlı seramik üretim merkezlerinde de sürekli tercih edilmiştir ${ }^{14}$. MS IV. yüzyıldan itibaren Sigillataların yerini alan "Geç Roma Kırmızı Astarlı Seramiğì" grubunda ise, hamur kalitesindeki azalmaya paralel olarak ince uygulanan düşük kalitedeki astar esastır. Kırmızı astarlı seramikleri erken ve geç dönem olmak üzere iki kronoloji grubunda toplayan bu kavramlar birçok araştırmacı tarafından kabul görür. Diğer yandan son dönem araştırmalarıyla, Roma seramik grubuna dahil olan Sagalassos Kırmızı Astarlı Seramikleri için bu tarz bir ayrıma gidilmemiştir. Poblome, MS I. yüzyıldan itibaren üretilmeye başlanan, Batı ve Doğu Sigillataları ile eş astar kalitesine sahip seramikler için yalnızca "Kırmızı Astarlı" tanımlamasını kullanmışıır15 ${ }^{15}$ Böylece MS I. yüzyıl ile III. yüzyıl arasında üretilen kaliteli kırmızı astarlı seramiklerle, geç dönem kırmızı astarlı seramikleri tek bir başlık altında toplayan farklı bir terminoloji önerisi sunmuştur ${ }^{16}$.

Kenyon'un yaptığı alfabetik kodlamaya göre ${ }^{17}$ Doğu Sigillatalarının ikinci grubu olan DSB’lerin üretimine Augustus döneminde başlanmış olup, üretim yeri olarak Batı Anadolu kıyıları gösterilmektedir ${ }^{18}$. Bu grup ilk kez, özellikle Pilinius' un Naturalis Historia kitabında yer alan ifadeden yola çıarak "Vasa Samia" ya da "Samos Kapları" olarak karşımıza çıkar19. H. S. Robinson, bu grubu sırasıyla Samos B ve Samos A olarak ${ }^{20}$, P. Hellström ${ }^{21}$ ise hamur - astar ve profil farklllıklarına göre DSB 1 ve DSB 2 olarak iki alt grupta değerlendirmiştir. Kenyon'un önerdiği alfabetik kodlama doğrultusunda, üretim merkezi Batı Anadolu olan bu grup, Doğu Sigillata B olarak adlandırılmış ${ }^{22}$ ve bilim dünyasında da bu şekilde kabul görmüştür. DSB grubunun üretim yeriyle ilgili farklı öneriler söz konusudur. Plinius (nat. XXXV 160, 161) Samos ve Tralleis' ${ }^{23}$, J. W. Hayes ise Menderes vadisindeki Tralleis’i gösterir ve Samos' un kesinlikle üretim yeri olmadığını belirtir ${ }^{24}$. C. Williams, Tenedos'u üretim merkezlerinden birisi olarak göstermektedir ${ }^{25}$. R. Meriç ise, Ephesos'u üretim merkezi olarak önerir $^{26}$. Bu önerilerin yanı sıra son dönemlerde yapılan kil analizleri ve diğer veriler üretim merke-

13 Zoroğlu 1986, 62-63; Yıldız 2016, 255.

14 Korkut \& Ișin 2015, 220.

15 Poblome 1999, 24-26; Uygun 2011, 4; Y1ldız 2016, 255.

16 Uygun 2011, 4.

17 Kenyon 1957, 282.

18 Tekocak 2019, 90.

19 Waagé 1933, 285, 291; Waagé 1948, 38; Robinson 1959, 12; Zoroğlu 1986, 62; Hayes 1972, 9-10; Özdilek 2018, 639; Tekocak 2019, 90.

20 Robinson 1959, 12.

21 Hellström 1965, 30.

22 Kenyon 1957, 282; Lund 2003, 125-126; Yıldız 2016, 255; Özdilek 2018, 639; Tekocak 2019, 90; Y1ldız 2019a, 109; Ylldiz 2019b, 248.

23 Takaoğlu 2006, 263.

24 Hayes 1985, 49; Tekocak 2019, 90.

25 Williams 1989, 19.

26 Meriç 2002, 80. 
zinin Tralleis olma olasıllğını arttırmıştır. Ayrıca Tralleis' in üretim merkezi olma olasıllğını güçlendiren bir başka veri de Notion'da bulunan bir seramik parçası üzerinde Tralleis kentinin Erken Roma İmparatorluğu Dönemi'ndeki ismi olan "CAESAREIA" baskısının bulunmuş olmasıdır ${ }^{27}$. Bu konudaki bir başka öneri ise Ephesos ve Tralleis kentlerinde bulunan DSB örnekleri üzerinde tespit edilen, Caius Sentius ve Quintus Pompeius Serenus gibi İtalyan ustaların isimlerinin varlı̆ğ kimi araştırmacılar tarafından, onların bu kentlerde şube kurmuş olabilecekleri şeklinde yorumlanmıştı ${ }^{28}$. DSB grubu kapsamlı bir şekilde J. W. Hayes tarafından ele alınmıştır. Hayes, 1985 yılında DSB- 1’i Form 150, DSB-2' yi de Form 51- 80 olarak tasnif etmiştir ${ }^{29}$.

DSB'ler, özenli kalıbı ve rulet dekorasyonu gibi farklı özellikleriyle Arretine seramiği ile oldukça yakın bir benzerliğe sahiptir. Hamuru genelde parlak kırmızı, portakal kırmızısı ve gözle görülebilecek kadar yoğun mika katkılıdır. Astarı oldukça sabunumsu olup genelde açık ve mat kırmızı, bazen de soluk portakal rengi, krem-beyaz ya da siyahtır. Hem kil hem de astar oldukça gözenekli sayılır. DSB-1 ve DSB-2'nin hamur ve astar yapısı fark edilebilecek derecede birbirlerinden farklıdır. DSB1'lerin pembemsi kahverengi hamuru sert, gümüş mika katkılı ve iyi fırınlanmıştır. Oldukça kaliteli olan astarı ise parlak ve koyu kırmızımsı turuncudur. DSB-2'lerin ise kırmızımsı hamuru yumuşak dokulu ve daha yoğun gümüş mika katkılı ve kötü fırınlanmıştır. Astarı ise soluk kırmızımsı turuncudur ${ }^{30}$. DSB'lerin en erken örneği muhtemelen Geç Augustus döneminde görülmüştür. İki alt gruba ayrılmış olan seri; Samos B=DSB-1 MÖ yaklaşık 10 - MS 75, Samos A=DSB-2 ise MS 75 - 150 yılları arasına tarihlendirilmektedir. Bu şekilde alt gruplara ayrılmasının nedeni MS I. yüzyılın III. çeyreğinde gerçekleşen bir değişim ile yeni kap formlarının ortaya çıkmasıdır ${ }^{31}$.

\section{Metropolis Aşağı Hamam Palaestra'daki DSB’lerin Hamur ve Astar Özellikleri}

\section{DSB 1}

Metropolis Aşağı Hamam Palaestra'da bulunan DSB 1 grubu örneklerinin hamurunun rengi kırmızının farklı tonlarındadır. Genellikle gümüş mika katkılı, sıkı, gözeneksiz ve sert pişimli kaliteli bir hamur dokusu görülür. Gruptaki örnekler Munsell renk kataloğuna göre 8 farklı hamur rengine sahiptir. Munsell kataloğundaki karşıllı̆ı 2,5 YR 4/8, 5/8, 6/6, 6/8, 7/8, 5 YR 4/6, 6/8, 10 R 6/8'dir. Astarı ise daldırma tekniğinde uygulanmıştır. Astar mat ve hafif sabunumsudur. Ayrıca kırmızıdan portakal rengine kadar değişkenlik gösterir. Grupta yer alan örneklerde Munsell renk kataloğuna göre 5 farklı astar rengi saptanmıştır. Astar renginin Munsell kataloğundaki karşılığ 2,5 YR 4/6, 4/8, 5/8, 10 R 5/6, 5/8’ dir.

\section{DSB 2}

Metropolis Aşağı Hamam Palaestra'da bulunan DSB 2 grubu örneklerinin hamur rengi genellikle DSB 1 grubundaki hamur renklerine benzemektedir. Bazen birkaç ton daha koyu hamur rengi görülebilir. Hamur yoğun gümüş mika katkılıdır. Katmanlaşmış hamur yapısı en belirgin özellik olarak dikkat çekmektedir. Gruptaki örnekler Munsell renk kataloğuna göre 11 farklı hamur rengine sahiptir. Bu renklerin Munsell kataloğundaki karşıllı̆̆ 2,5 YR 4/6, 5/6, 5/8, 6/6, 6/8, 7/4, 7/8, 5 YR 5/6, 6/8,

\footnotetext{
27 Uygun 2011, 10; Özdilek 2018, 639.

28 Takaoğlu 2006, 264-265; Uygun 2011, 11, 127-128; Özdilek 2018, 639.

29 Hayes 1985, 49-70 lev. XI-XV.

30 Hayes 1973, 452; Özdilek 2018, 641; Tekocak 2019, 90.

31 Hayes 1973, 455, 468; Özdilek 2018, 640; Tekocak 2019, 90-91.
} 
10 R 5/8 ve 6/6'dır. Astar rengi, portakalımsı kırmızı gibi açık tonlardadır. Bu gruba dahil edilen örneklerin profil birleşme yerlerinde, astar daha yoğun olduğu için, ince çizgi ya da çatlaklar oluşmaktadır. Ayrıca bu grupta yine bazı formların varyasyonlarında ve imitasyonlarında kırmızı rengin farklı tonları da mevcuttur. Hatta bu gruptaki örneklerin bazılarında renk dalgalanmaları da görülmektedir. Grupta yer alan örneklerde Munsell renk kataloğuna göre 5 farklı astar rengi saptanmıştır. Astar renginin Munsell kataloğundaki karşıllğı 2,5 YR 4/8, 5/8, 10 R 4/8, 5/6 ve 5/8'dir.

\section{Tipolojik Değerlendirme}

\section{DSB 1 Formları}

Aşağı Hamam Palaestra'da bulunan DSB grubu örnekleri hamur, astar ve form farklılıklarına göre DSB 1 ve DSB 2 olmak üzere iki ana grupta ele alınmıștır. Yapıda bulunan DSB örneklerinden 12 adet seramik DSB 1 grubu içerisinde değerlendirilmiștir. Bu grubun tipolojisinin oluşturulmasında J. Hayes'in oluşturduğu tipoloji örnek alınmıștı ${ }^{32}$. Bu gruba giren 8 farklı tabak ve kase formu tespit edilmiştir (bk. Fig. 6).

\section{Mtr Așağı Hamam Palaestra Form 1-Hayes Form 5 (Kat. No. 1; Fig. 9)}

İçe dönük ağız kenarlı, yuvarlak bitimli dudaklı, dışa taşkın dirsek profilli, yuvarlak gövdeli, alçak halka kaideli sığ tabak formudur. Metropolis Așağı Hamam Palaestra yapısında bu form tipine ait tek bir örneğe rastlanmıştır. Bu forma giren örnek ağız kenarı-gövde parçasıdır. Söz konusu örnek DSB 1 grubunda yer alan Hayes Form 5 ile form özellikleri açısından benzeşirken dışa taşkın dirsek profilinin daha yumuşak olmasıyla Hayes Form 5 'ten az da olsa farklıdır. Ayrıca formun karakteristik özelliği olan dudak üzerindeki rulet bezeme ve yivlerle hareketlendirilmiş ağız kenarı profili Metropolis örneğinde görülmez. Ancak genel form özellikleri açısından değerlendirildiğinde Mtr Aşağı Hamam Palaestra Form 1, Hayes Form 5 grubunda ele alınmalıdır. Hayes bu formu, Arretine seramik tipolojisinden Haltern Tip 2'nin doğu taklidi olarak tanımlamıştır ${ }^{33}$. Ayrıca bu formun örneklerinin Atina Agorası'nda ${ }^{34}$, Priene'de, Keramaikos'ta ve Labraunda'da bulunduğunu belirtmiştir ${ }^{35}$. Karşlaştırma örnekleri açısından Mtr Așağı Hamam Palaestra Form l'in en yakın ve en yoğun örnekleri Ephesos'ta bulunmuștur. Meriç, kuyu buluntuları arasında bu forma ait 8 farklı örnek kataloglamıştır. Bu örnekler kendi içinde form çeşitliliği sunmaktadır. Ayrıca Meriç bu tabakları Hayes Form 5 grubunda değerlendirmesine rağmen, Hayes' in önerdiği MS I. yüzyılın ikinci çeyreği tarihini kabul etmez. Buna gerekçe olarak da aynı formun Mitsopoulos-Leon tarafından MS I. yüzyılın birinci çeyreğine tarihlenmesini ve de kuyu kazısında tespit edilen stratigrafinin de bu görüşü desteklediğini belirtir ${ }^{36}$. Formun, Ephesos'taki diğer benzer örnekleri Bazilika' da ${ }^{37}$, Tetragonos Agorası Güney Kapısı̉nda ${ }^{38}, 2$ numaralı Yamaç Ev' de ${ }^{39}$ saptanmıştır. Mtr

\footnotetext{
32 Hayes 1985, 49-70.

33 Uygun 2011, 48.

34 Hayes 2008, 142 fig. 8/200.

35 Hayes 1985, 54; Uygun 2011, 48.

36 Meriç 2002, 49; Uygun 2011, 48.

37 Mitsopoulos-Leon 1991, 100-101, taf. 120/H25.

38 Gassner 1997, 127 taf. 42/495.

39 Ladstatter 2000, abb. 5.
} 
Așağı Hamam Palaestra Form l'in bir diğer yakın benzeri de Patara' da bulunmuştur ${ }^{40}$. Söz konusu formun benzer örnekleri Tralleis'te Erol tarafından saptanmış ve iki alt grupta ele alınmıştır ${ }^{41}$. Formla ilgili olarak gerek form özellikleri ve kalitesi gerekse cidar kalınlığı ve kontekstler göz önünde bulundurularak farklı tarihleme önerileri getirilmiştir. Tarihleme konusunda form için en erken öneri MS I. yüzyılın birinci yarısı ile Ephesos örneklerinden gelir ${ }^{42}$. Hayes' in önerisi ise MS I. yüzyılın ikinci çeyreğidir ${ }^{43}$. Korinthos ve Knossos örnekleri de Tiberius dönemine tarihlendirilmiștir ${ }^{44}$. Tralleis ${ }^{45}$ ve Patara ${ }^{46}$ örnekleri ise MS I. yüzyılın ilk yarısına tarihlendirilmiştir. En geç öneri ise kontekste göre Flaviuslar dönemine tarihlenen Ephesos 2 numaralı Yamaç Ev'de bulunan tabaktır ${ }^{47}$. Bu örnekler ve farklı tarihleme önerileri Hayes Form 5 'in kullanım süresinin uzunluğu göstermesi açısından oldukça önemlidir. Mtr Aşağı Hamam Palaestra Form 1 ise MS I. yüzyılın ilk yarısına tarihlendirilmelidir.

\section{Mtr Aşağı Hamam Palaestra Form 2-Hayes Form 23 (Kat. No. 2-4; Fig. 10.1-3)}

Dik ağızlı, yuvarlak dudaklı, yarım küre gövdeli, alçak halka kaideli derin kase formudur. Aşağı Hamam Palaestra yapısında bu gruba giren üçörnek saptanmıştır. Bu örneklerden Kat. No. 2 ağız kenarı-gövde parçası, Kat. No. 3-4 ise kaide-gövde parçasıdır. Bu seramikler Hayes Form 23 grubu ile form özellikleri açısından benzeşir. Ağız kenarı-gövde parçası olan Kat. No. 2 yarım küre gövde yapısıyla bu forma oldukça benzerken kenarın genel özelliği ile bu formdan farklıdır. Ayrıca bu örnek büyük olasılıkla alçak halka kaide ile sonlanmalıdır. Dolayısıyla genel form özellikleri açısından Hayes Form 23 ile benzeşir ${ }^{48}$. Kat. No. 2'nin karşılaştırma örnekleri oldukça sınırlıdır. Kat. No. 2'nin en yakın benzerlerine Assos'ta ${ }^{49}$ ve Ephesos Meryem Ana Kilisesi’nde ${ }^{50}$ rastlanmıştır. Assos örnekleri Hayes Form 23 ile bağlantılı görülürken Ephesos Meryem Ana Kilisesìnde bulunan kase için herhangi bir form önerisi getirilmemiştir.

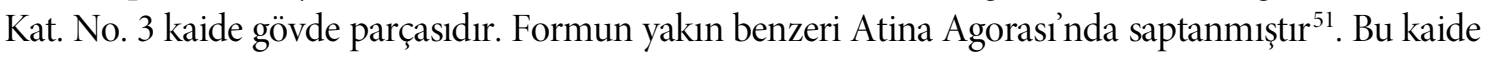
gövde parçasının tondosunda iki sıra yiv bezeme görülmektedir. Merkezdeki yiv bezemenin içinde dikdörtgen çerçeve içine yerleştirilmiş ve tek satırdan oluşan " $E P M H{ }^{5}$ " damgası mevcuttur (bk. Fig. 7; 10.2). Bu damgayla ilgili ilk çalışma Iliffe tarafından gerçekleştirilmiştir. Iliffe söz konusu damgayı İ grubunda değerlendirmiş ve Augustus dönemine tarihlendirmiştir ${ }^{53}$. Ayrıca Iliffe'nin ele aldığı örnekler

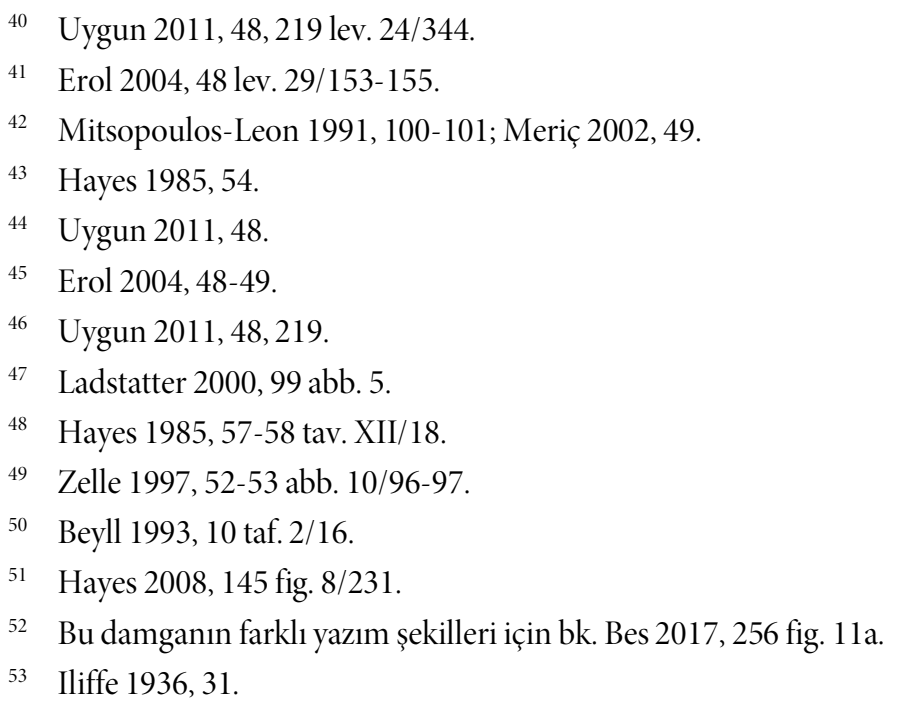


Antiokheia' da ${ }^{54}$, Aleksandria' da, Tarsus Gözlükule'de ${ }^{55}$, Priene'de ve Güney Rusya' da ele geçmiştir ${ }^{56}$.

Bu damga ile ilgili farklı bir öneri Lund tarafından yapılmıştır. Lund, “ $E P M H \Sigma$ ” damgası ile farklı seçeneklerin de olabileceğini ve hatta tanrı Hermes ile ilgili bağlantının göz ardı edilmemesi gerektiğini belirtir ${ }^{57}$. Damga ile ilgili en kapsamlı ve en güncel yayın Bes tarafından yapılmıştır ${ }^{58}$. Bes "EPMH $\Sigma$ " damgasının bir kişiye ait isim olup olmadığı konusunun net olmadığını söylemesine rağmen damgayı isim/çömlekçi olarak yorumlamıştır. Bu durumu açılarken de kişi isimlerinin seramikler üzerinde genellikle genetiv hallerinin kullanıldığını ancak “ $E P M H \Sigma$ ” ve "A tanrı ve tanrıça isimlerinin de yer aldığı bazı isimlerin genetiv hallerinin kullanıldığı örneklerin olmadığını belirtir. Buradan hareketle de " $E P M H \Sigma$ " damgasının dinî bir öneminin olduğunu ve daha geniş bir bağlantıyı da temsil edebileceğinin de üzerinde durmaktadır ${ }^{59}$. Damganın bire bir ya da farklı şekillerde yazılmış benzerleri başta Ephesos'un farklı çalışma alanlarından gelmektedir. Bu örnekler Bazilika' da ${ }^{60}$, Ephesos Kuyu seramikleri arasında ${ }^{61}$ ve 2 numaralı Yamaç Ev' de ${ }^{62}$ saptanmıştır. Ayrıca 2 numaralı Yamaç Ev'de erken imparatorluk dolgusunda bulunan örnekler çömlekçi ismi olarak değerlendirilmiştir ${ }^{63}$. Ephesos dışında damganın örnekleriyle Stobi'de ${ }^{64}$, Tralleis'te ${ }^{65}, S_{y m r n a} \mathrm{da}^{66}$, Atina Agorası'nda ${ }^{67}$ ve Patara' da ${ }^{68}$ karşılaşılmıştır. Damganın saptandığ 1 karşılaştırma örneklerinden form tespiti yapılabilenler arasında bir form birlikteliği olmadığı görülmektedir. Bu bağlamda bakıldiğginda damga, DSB I grubunda Hayes Form $6^{69}, 17 \mathrm{a}^{70}, 29,{ }^{71} 38^{72}$ ile DSB II grubunda Hayes Form $58^{73}, 59^{74}, 60^{75} \mathrm{ve}^{6} 6^{\prime} \mathrm{da}^{76}$ tespit edilmiştir. Formlarda görülmeyen birliktelik damganın yazım şekillerinde de görülmemektedir. " $E P M H \Sigma$ " damgasının farklı şekillerde yazılarak oldukça geniş bir coğ-

54 Waage 1948, 35-36.

55 Jones 1950, 284 fig. 176/903.

56 Iliffe 1936, 31; Uygun 2011, 62-63.

57 Lund 2016, 838.

58 Bes 2017, 241-272.

59 Bes 2017, 254-255.

60 Mitsopoulos-Leon 1991, 96-97, 103, 116 taf. 145/H 109.

61 Meriç 2002, 49-50.

62 Ladstatter 2005, 260, 353 taf. 204/K 872; Ladstatter \& Liedl 2020, 28 taf. 2/K 23, taf. 3/K 30, taf. 5/K 69.

63 Ladstatter \& Liedl 2020, 28.

64 Anderson-Stojanovic 1992, 53 pl. 39/339.

65 Erol 2004, 65 lev. 83-84, 394-399; Takaoğlu 2006, 264, 268 fig.2.

66 Erol 2007, 79 çiz. 32.

67 Hayes 2008, 143 pl. 6/207.

68 Uygun 2011, 62-63 lev. 25/372, lev. 27/394.

69 Meriç 2002, 49-50.

70 Uygun 2011, 62-63 lev. 25/372.

71 Erol 2004, 65 lev. 84/398-399.

72 Meriç 2002, 49-50.

73 Erol 2004, 65 lev. 83/395.

74 Ladstatter 2005, 260, 353 taf. 204/K 872; Ladstatter \& Liedl 2020, 28 taf. 2/K 23 taf. 3/K 30 taf. 5/K 69.

75 Ladstatter 2005, 260, 353 taf. 204/K 872; Ladstatter \& Liedl 2020, 28 taf. 2/K 23 taf. 3/K 30 taf. 5/K 69.

76 Erol 2004, 65 lev. 84/397. 
rafyaya yayıldığını görmekteyiz. Söz konusu karşılaștırma örneklerinin yardımıyla damga MS I. yüzyılın ilk yarısına tarihlendirilebilir.

Aşağı Hamam Palaestra yapısında bu forma giren son örnek Kat. No. 4’tür. Bu örnek kaide gövde parçasıdır. Alçak halka kaide olması ve genel form özellikleri açısından Hayes Form 23 grubunda ele alınmıştır. Kat. No. 4 'ün yakın benzerleriyle Ephesos Kuyu Buluntuları arasında ${ }^{77}$ ve Patara da $^{78}$ karşılaşılmıştır. Mtr Așağı Hamam Palaestra Form 2 grubuna giren örnekler gerek farklı merkezlerdeki benzerleri gerekse Kat. No. 3 'ün tondosundaki damganın yardımıyla MS I. yüzyılın ilk yarısına tarihlendirilmelidir.

\section{Mtr Aşağı Hamam Palaestra Form 3-Hayes Form 24 (Kat. No. 5; Fig. 11)}

Dik ya da hafif dışa açılan kenarlı, kaideye doğru daralan yuvarlak gövdeli, alçak halka kaideli kase formudur. Aşağı Hamam Palaestra' da bu gruba giren tek örnek saptanmıştır. Kat. No. 5 kaide parçasıdır. Söz konusu örnek geniş kaide çapı, alçak halka kaidesi, kaidesinin ince cidarlı olması ve oldukça hareketli kaide ile kaidesindeki köşeli kademe profili nedeniyle Hayes Form 24 grubuna ait olmalıdır. Hayes Form 23 ve 24 birbirine yakın formlardır. İki form arasında küçük farklılıklar mevcuttur. Hayes Form 24, 23' e göre daha geniş gövdeli ve daha alçak halka kaidelidir ${ }^{79}$. Formun yakın benzerleri Atina Agorası'nda ${ }^{80}$, Korinthos'ta ${ }^{81}$ ve Ephesos Kuyu buluntuları arasında saptanmıștı ${ }^{82}$. Mtr Așağ 1 Hamam Palaestra Form 3, karşılaştırma örneklerinin yardımı ve Hayes'in önerisi doğrultusunda MS I. yüzyılın ilk yarısına tarihlendirilebilir.

\section{Mtr Aşağı Hamam Palaestra Form 4-Hayes Form 27 (Kat. No. 6; Fig. 12)}

Dik kenarlı, yuvarlak ya da konik gövdeli, dış konturu kademeli ve dışa açılan yüksek halka kaideli küçük kase formudur. Metropolis Aşağı Hamam Palaestra'da bu forma ait tek örnek tespit edilmiştir. Söz konusu örnek de kaide-gövde parçasıdır. Kat. No. 6 nın kaidesi oldukça yüksekken gövde yapısı yuvarlak formludur. Ayrıca kaide profili oldukça hareketlendirilmiştir. Kat. No. 6 gerek kaide gerekse gövde özellikleri nedeniyle Hayes Form 27 grubunda ele alınmıştır. Hayes, Form 27'nin, Form 26 ile bağlantılı olduğunu belirtir. Ayrıca Form 27'nin prototipinin DSA Hayes Form 48-49 olduğunu söyler ${ }^{83}$. Formun karşılaştırma örnekleri oldukça sınırlıdır. Aşağı Hamam Palaestra kasesinin yakın benzeri Patara'da bulunmuştur. Patara örnekleri MS I. yüzyllın ilk yarısına tarihlendirilmiştir ${ }^{84}$. Metropolis örneği olan kase de gerek Patara örneği gerekse Hayes' in ${ }^{85}$ önerisi doğrultusunda MS I. yüzyılın ilk yarısına tarihlendirilmelidir.

\section{Mtr Aşağı Hamam Palaestra Form 5-Hayes Form 28 (Kat. No. 7-8; Fig. 13.1-2)}

Dışa taşkın dudaklı, kaideye doğru daralan dışbükey gövdeli ya da yarım küre gövdeli, yüksek halka kaideli kase formudur. Metropolis Așağı Hamam Palaestra' da bu forma ait iki örnek saptanmıştır. Kat. No. 7, ağız kenarı-gövde parçası iken Kat. No. 8 kaide-gövde parçasıdır. Her iki örnek de ağıZ

77 Meriç 2002, 64 taf. 27/K 295.

78 Uygun 2011, 57, 225 lev. 26/393.

79 Hayes 1985, 58.

80 Waage 1933, 292 fig. 1/99, pl. IX/99.

81 Hayes 1973, 454 pl. 86/143; 1985, 58 tav. XII/19.

82 Meriç 2002, 51 taf. 23/K 221- K222.

83 Hayes 1985, 58.

84 Uygun 2011, 58, 226 lev. 27/402.

85 Hayes 1985, 58 tav. XII/23. 
kenarı, gövde ve kaide profillerinin özellikleri açısından Hayes Form 28 grubuna ait olmalıdır. Kat. No. 7, dışa taşkın dudak ve dışa açlan gövde yapısıyla Patara'da saptanan Kat. No. 401 nolu parça ile oldukça benzerdir ${ }^{86}$. Metropolis örneğinin Patara örneğinden farklı yönü ise oldukça ince cidarlı bir kenar profiline sahip olmasıdır. Kat. No. 7'nin bir diğer yakın benzeri Ephesos'ta 2 numaralı Yamaç Ev'de Erken İmparatorluk Dönemi dolgusuna ait seramikler arasında ${ }^{87}$ ve Atina Agorasinda ${ }^{88}$ tespit edilmiştir. Kaide-gövde parçası olan Kat. No. $8^{\prime}$ in yakın benzeri ise Atina Agorası'nda saptanmıștır ${ }^{89}$. Atina Agorası ve Patara örneklerinden hareketle Mtr Aşağı Hamam Palaestra Form 5 örnekleri MS I. yüzyılın ilk yarısına tarihlendirilmelidir.

\section{Mtr Aşağı Hamam Palaestra Form 6-Hayes Form 29 (Kat. No. 9-10; Fig. 14.1-2)}

Yuvarlak veya sivri bitimli dudakl, yarım küre gövdeli, alçak halka kaideli kase formudur. Metropolis Aşağı Hamam Palaestra'da bu forma ait iki örnek saptanmıştır. Saptanan iki örnek de kaide-gövde parçasıdır. Gerek kaide özellikleri gerekse gövde yapısı bakımından bu kaseler Hayes Form 29 grubu ile benzeşmektedir. Hayes, bu formun DSB 2 grubundaki Hayes Form 66' nın prototipi olduğunu belirtir ${ }^{90}$. Kat. No. 9'un benzerleri başta Metropolis Peristilli Ev'de ${ }^{91}$ olmak üzere Ephesos Kuyu seramikleri arasında ${ }^{92}$, Laodikeia' $\mathrm{da}^{93}$ ve Patara' $\mathrm{da}^{94}$ tespit edilmiştir. Kat. No. $10^{\prime}$ un benzer örnekleri ise yine Ephesos Kuyu seramikleri arasında ${ }^{95}$ ve Patara' $\mathrm{da}^{96}$ saptanmıştır. Metropolis kaseleri benzer örneklerin yardımı ve Hayes' in önerisinden ${ }^{97}$ hareketle MS I. yüzyılın ilk yarısına tarihlendirilebilir.

\section{Mtr Așağı Hamam Palaestra Form 7-Hayes Form 34 (Kat. No. 11; Fig. 15)}

Dışa uzantılı ağız kenarlı, kaideye doğru daralan iç bükey gövdeli, hafif belirginleștirilmiş ya da kendinden kaideli kase formudur. Dudak üzerinde, gövdenin üzerinde ve tondoda yiv bezeme olması formun karakteristik özelliğidir. Metropolis Aşağı Hamam Palaestra yapısında bu forma giren tek örnek saptanmıştır. Kat. No. 11, kaide gövde parçası olup ne yazık ki ağız kenarı eksiktir. Aşağı Hamam Palaestra örneğinde de formun genel özelliği olan hem gövdenin iç yüzünde hem de tondoda yiv bezeme tespit edilmiştir. Bu formun karşılaştırma örnekleri oldukça sınırlıdır. Formun tipolojisi Hayes tarafından yapılmıştır ${ }^{98}$. Hayes, bu formun Hayes Form $17 \mathrm{~b}$ ile bağlantılı olduğunu belirtir ${ }^{99}$. Formun en yakın benzeri Tralleis’te bulunmuştur. Ancak bu örneğin tipolojisi yapılmamıștır ${ }^{100}$. Mtr Aşağı Hamam Palaestra Form 7, hem Hayes'in önerisi hem de Tralleis'te bulunan örneğin üzerindeki damganın yardımıyla MS I. yüzyılın ilk yarısına tarihlendirilebilir.

86 Uygun 2011, 58, 226 lev. 27/401.

87 Ladstatter \& Liedl 2020, 42 taf. 69/K 55.

88 Hayes 1985, 58 tav. XII/24; 2008, 148-149 fig. 10/275.

89 Hayes 2008, 148 fig. 10/271.

90 Hayes 1985, 59.

91 Aybek et al. 2021, 26-27, 76 pl. 17/cat.149.

92 Meriç 2002, 51-52, 60 taf. 23/K 228.

93 Şimşek et al. 2011, 115 lev. 103/358.

94 Uygun 2011, 57, 225-226 lev. 27/395.

95 Meriç 2002, 51-52, 60 taf. 23/K 227.

96 Uygun 2011, 57, 226 lev. 27/397.

97 Hayes 1985, 59 tav. XII/26-27.

98 Hayes 1985, 60 tav. XIII/4.

99 Hayes 1985, 60.

100 Erol 2004, 64, 209 lev. 80/380. 


\section{Mtr Aşağı Hamam Palaestra Form 8-Hayes Form 36 (Kat. No. 12; Fig. 16)}

Kısa ve dik dudaklı, kaideye doğru daralan konik gövdeli, hafif belirginleștirilmiş ya da kendinden kaideli kase formudur. Metropolis Așağı Hamam Palaestra' da bu forma giren tek örnek saptanmıștır. Kat. No. 12, kaide gövde parçası olup tıpkı Kat. No. 11 gibi ağız kenarı eksiktir. Tipolojisi Hayes tarafından yapılan ${ }^{101}$ formun karşılaştırma örnekleri sadece Ephesos'ta saptanmıştır. Dolayısıyla bu form Ephesos ve Metropolis dışında henüz başka bir kentte tespit edilmemiştir. Hayes bu formun Hayes Form 20 ile bağlantılı olduğunu belirtir. Ayrıca hem Hayes Form 20'nin hem de Hayes Form 36'nın örnekleri Ephesos buluntusudur ${ }^{102}$. Metropolis örneği kase de Hayes'in önerisi doğrultusunda MS I. yüzyılın ilk yarısına tarihlendirilmelidir.

\section{DSB 2 Formları}

Aşağı Hamam Palaestra' da bulunan DSB örneklerinden 38 adet seramik DSB 2 grubu içerisinde değerlendirilmiştir. Bu grubun tipolojisinin oluşturulmasında J. Hayes'in oluşturduğu tipoloji örnek alınmıştır ${ }^{103}$. Bu gruba giren 9 farklı tabak ve kase formu tespit edilmiştir (bk. Fig. 6).

\section{Mtr Aşağı Hamam Palaestra Form 9-Hayes Form 53 (Kat. No. 13-14; Fig. 17.1-2)}

İçe dönük ağız kenarlı, yuvarlak bitimli dudaklı, yuvarlak profille kaideye yönelen dışbükey gövdeli ve dış konturu düz inen alçak halka kaideli tabak formudur. Așağı Hamam Palaestra’da bu forma giren iki örnek saptanmıştır. Kat. No. 13 tam profil verirken Kat. No. 14 kaide-gövde parçasıdır. Kat. No. 14 'ün tondosunun merkezinde yiv bezeme görülmektedir. Özellikle tam profil veren örnekten hareketle bu tabaklar Hayes Form 53 grubunda değerlendirilmiştir. Bu formun yakın benzeri DSB 1 grubunda da mevcut olup bu form Hayes tarafından Form $14^{104}$ olarak sınıflandırılmıştır. DSB 1 grubundaki Hayes Form 14, Hayes Form 53'ün prototipidir. Ayrıca iki yakın form arasında farklılıklar da görülmektedir. Hayes Form 14, Hayes Form 53'e göre daha ince cidarlı ve daha sığdır. Ayrıca Hayes Form 14'ün kaidesindeki profillendirme ve Form 53'e göre daha alçak kaideli olması da Hayes Form 53'ten diğer farklı özellikleridir. Mtr Aşağı Hamam Palaestra Form 9 karşlaştırma örnekleri açısından oldukça zengindir. Formun yakın benzerleriyle çok geniş bir coğrafyada karşılaşlır. Bu grubun henüz DSB olarak tanımlanmadığ 1 süreçte Antiokheia'da ${ }^{105}$ ve Tarsus Gözlükule' de ${ }^{106}$ bu formun yakın benzerleri Samian Seramiği başlı̆̆ında ele alınmıştır. Formun diğer yakın benzerleri ise Knossos'ta ${ }^{107}$, Tralleis'te ${ }^{108}$, Patara' da ${ }^{109}$ ve Ephesos 2 numaralı Yamaç Ev' de ${ }^{110}$ saptanmıştır. Bu form, diğer Doğu Sigillata gruplarında da sıklıkla karşılaşılan servis tabaklarındandır. Örneğin, formun yakın benzerleri DSC ${ }^{111}$ ve Sagalassos Kırmızı

\footnotetext{
101 Hayes 1985, 60 tav. XIII/6.

102 Heberdey 1906, 173/52; Hayes 1985, 57, 60.

103 Hayes 1985, 49-70.

104 Hayes 1985, 56 tav. XII/6.

105 Waage 1948, $38 \mathrm{pl}$. VI/S2.

106 Jones 1950, 253 fig. 147/555, fig. 197/555.

107 Sackett 1992, 157 pl.156/9.

108 Erol 2004, 71-72 lev. 92/433.

109 Uygun 2011, 66, 231 lev. 29/434.

110 Ladstatter \& Liedl 2020, 25-26, 38 taf. 2/K 14.

111 Hayes 1985, 75-76 tav. XVII/1.
} 
Astarlı Seramiği örneklerinde ${ }^{112}$ küçük profil değişiklikleriyle karşımıza çıkar ${ }^{113}$. Bu kadar farklı merkezde ele geçen Mtr Așağı Hamam Palaestra Form 9'un benzerleri için verilen tarih önerisi MS I. yüzyılın ikinci yarısıdır. Bu tarih Metropolis Așağı Hamam Palaestra tabakları için de uygun olmalıdır.

\section{Mtr Aşağı Hamam Palaestra Form 10-Hayes Form 55 (Kat. No. 15-18; Fig. 18.1-4)}

Dışa uzantılı ağız kenarlı, kısa dışbükey profilli gövdeli, hafif belirginleştirilmiş ya da kendinden kaideli sığ tabak formudur. Aşağı Hamam Palaestra yapısında bu gruba giren dört örnek saptanmıștır. Bunlardan Kat. No. 15-17 ağız kenarı-gövde parçasıyken Kat. No. 18 tam profil vermektedir. Metropolis Aşağı Hamam Palaestra'da bulunan bu örnekler Hayes Form 55 grubu içerisine girmektedir. Kat. No. 15-17 kenar ve gövde özellikleri açısından birbirinin nerdeyse aynısıdır. Sadece ağız çapları farklıdır. Bu üç tabağın en yakın benzeri Ephesos Tetragonos Agorası Güney Kapısı’nda ele geçmiştir. Ancak bu örnek dudak profilindeki farklılık nedeniyle Hayes Form 55 grubunda ele alınmamış ve herhangi bir grup belirtilmemiştir ${ }^{114}$. Bu üç tabağın diğer benzeri ise Patara' $\mathrm{da}^{115}$ bulunmuştur. Patara örnekleri MÖ I. yüzyılın ikinci yarısı ile MS I. yüzyıl içerisine tarihlenen DSA grubundan Samaria Form 5 ile bağlantılı görülmüştür. Özellikle bu formun dudak ve kısa gövde profili açısından görülen benzerlikten hareketle Patara tabakları MS I. yüzyılın üçüncü çeyreği yoğun olmak üzere MS I. yüzyılın ikinci yarısının sonlarına kadar tarihlenmiştir ${ }^{116}$. Kat. No. 15-17 kenar ve gövde özellikleri açısından Patara Kat. No. 436 ile oldukça yakındır. Bu üç tabak gerek Hayes'in önerisi ${ }^{117}$ gerekse Patara tabaklarının yardımıyla MS I. yüzyılın ikinci yarısına tarihlendirilebilir. Genel form özellikleriyle Hayes Form 55 grubunda değerlendirilen Kat. No. 18 diğer üç tabaktan farklıdır. Özellikle dudak üzerinin düz olmaması ve ağız kenarının hafif aşağı dönük olmasıyla diğer örneklerden ayrılır. Kaidesi de Hayes Form 55'e göre az da olsa farklıdır. Hafif belirginleştirilmiş bir kaide yapısı söz konusudur. Ancak genel karakteristik özellikleri açısından Hayes Form 55 grubuna benzemektedir. Aşağı Hamam Palaestra'dan bulunan bu sığ tabak olasılıkla Hayes Form 55 'in varyasyonu olmalıdır. Hayes'in tipolojisinde bu gruba giren iki örnek kataloglanmıştır. Bunlardan birisi tam profil verirken diğeri kaide gövde parçasıdır ${ }^{118}$. Dolayısıyla bu formun nadir bulunan bir form olduğu söylenebilir. Bu bağlamda bakıldığında Kat. No. 18'in benzer örnekleri Ephesos 2 numaralı Yamaç Ev'de bulunmuştur. Ephesos örnekleri de form özelliklerinden hareketle Hayes Form 55 grubunda değerlendirilmiştir ${ }^{119}$. Bu formun bir diğer benzeri ise Atina Agorası'nda saptanmıştır. Hayes bu örneği sınıflandırılmamış formlar arasında değerlendirmiştir. Ayrıca bu formla ilgili olarak metal kapların taklidi olduğunu belirtmiştir ${ }^{120}$. Söz konusu form gerek Atina Agorası örneğinin gerekse Ephesos örneklerinin yardımılla MS II. yüzyıla tarihlendirilir. Bu bağlamda bakıldığında bu varyasyon ile Hayes Form 55 'in MS I. yüzyılın ikinci yarısı ile MS II. yüzyıl arasında uzun bir süre üretiminin ve kullanımının devam ettiği görülmektedir.

\footnotetext{
112 Poblome 1999, 308 fig. 51/8-9.

113 Uygun 2011, 66.

114 Gassner 1997, 133 taf. 43/512.

115 Uygun 2011, 66, 231 lev. 29/436.

116 Uygun 2011, 66.

117 Hayes 1985, 62 tav. XIII/18.

118 Hayes 1985, 62 tav. XIII/18-19.

119 Ladstatter 2005, 240, 318 taf. 180/K 521; 2010, 178, 214 taf. 76/A-K 191.

120 Hayes 2008, 40, 155 fig. 12/344.
} 
Mtr Aşağı Hamam Palaestra Form 11-Hayes Form 58 (Kat. No. 19-26; Fig. 19.1-8)

İçe dönük ya da düz ağız kenarlı, yuvarlak bitimli dudaklı, yivlerle hareketlendirilmiş yatay dirsekli, kaideye doğru daralan eğik gövdeli ve alçak halka kaideli tabak formudur. Aşağı Hamam Palaestra'da en yoğun bulunan DSB formlarından birisidir. Bu forma ait 8 örnek saptanmıștır. Kat. No. 19-22 ağıZ kenarı-gövde parçası, Kat. No. 23-24 kaide gövde parçası, Kat. No. 25-26 tam profil veren örneklerdir. Aşağı Hamam Palaestra örnekleri genel profil özellikleri açısından Hayes Form 58 grubu içerisine girmektedir. DSB grubu seramikleri arasında bu form karşılaştırma örnekleri açısından çok zengindir. Mtr Aşağı Hamam Palaestra Form 11'in en yoğun bulunduğu merkezlerin başında Ephesos gelmektedir. Ephesos'un farklı çalışma alanlarında bu formun gerek nicelik bakımından gerekse profil çeşitliliği bakımından birçok örneği saptanmıştır. Kat. No. 19-22'nin benzerleri ile Ephesos'ta Meryem Ana Kilisesi'nde ${ }^{121}, 2$ numaralı Yamaç Ev'de ${ }^{122}$, Devlet Agorası Kuyu buluntularında ${ }^{123}$ ve Vedius Gymnasium' unda ${ }^{124}$ karşılaşılmıştır. Ephesos dışında ise Atina Agorası ${ }^{125}$ ve Patara' da ${ }^{126}$ Kat. No. 19-22'nin benzerleri tespit edilmiştir. Bu ağız kenarı parçalarından Kat. No. 21'in kenar dış yüzünde ve dirsek kısmında rulet bezeme görülmektedir (bk. Fig. 7; 19.3). Kat. No. 23 ve 24 'ün benzerleriyle başta Metropolis Peristilli Ev ${ }^{127}$ olmak üzere Ephesos'ta Meryem Ana Kilisesi'nde ${ }^{128}$, Devlet Agorası Kuyu buluntularında ${ }^{129}$ ve 2 numaralı Yamaç Ev'de ${ }^{130}$ karşılaşılmıştır. Diğer benzer örnekleri ise Atina Agorass ${ }^{131}$, Tralleis ${ }^{132}$ ve Patara'dan ${ }^{133}$ gelmiştir. Kat. No. 24 'ün tondosunun merkezinde baskı olarak yapılmış yiv ve palmet bezeme görülür (bk. Fig. 7; 19.6). Aşağı Hamam Palaestra'da bu forma dahil edilen son iki örnek tam profil veren Kat. No. 25 ve 26 dır. Bu örneklerden Kat. No. 25 , genel form özellikleri açısından değerlendirildiğinde Hayes Form 58 grubuna oldukça benzerken kısa kenarlı olması, daha sığ olması ve kalın cidarı ile bu formdan ayrılmaktadır. Kat. No. 26 ise dik kenarlı olması, sığ olması, kalın cidarı ve artık daha belirgin ve geniş halka kaidesiyle Hayes Form 58'den ayrllır. Ayrıca bu iki örneğin astar kaliteleri de grubun diğer örneklerine göre oldukça kötüdür. Hatta bu iki örneğin astar özellikleri Geç Roma Kırmızı Astarlı Seramiklerinin astar özelliklerini anımsatmaktadır. Bu iki örnek olasılıkla Hayes Form 58 ' in yerel atölyelerde üretilen imitasyonları olmalıdır. Kat. No. 25 ve 26 'nın benzerleri Ephesos'ta 2 numaralı Yamaç Ev'de ${ }^{134}$ ve Metropolis Ada $7^{135}$ seramikleri arasında saptanmıştır. Özellikle Ephesos 2 numaralı Yamaç Ev'de saptanan Metropolis örneklerinin benzerleri Hayes Form 58 grubunda değerlendirilmiştir. Ayrıca bunlar Yamaç Ev’deki

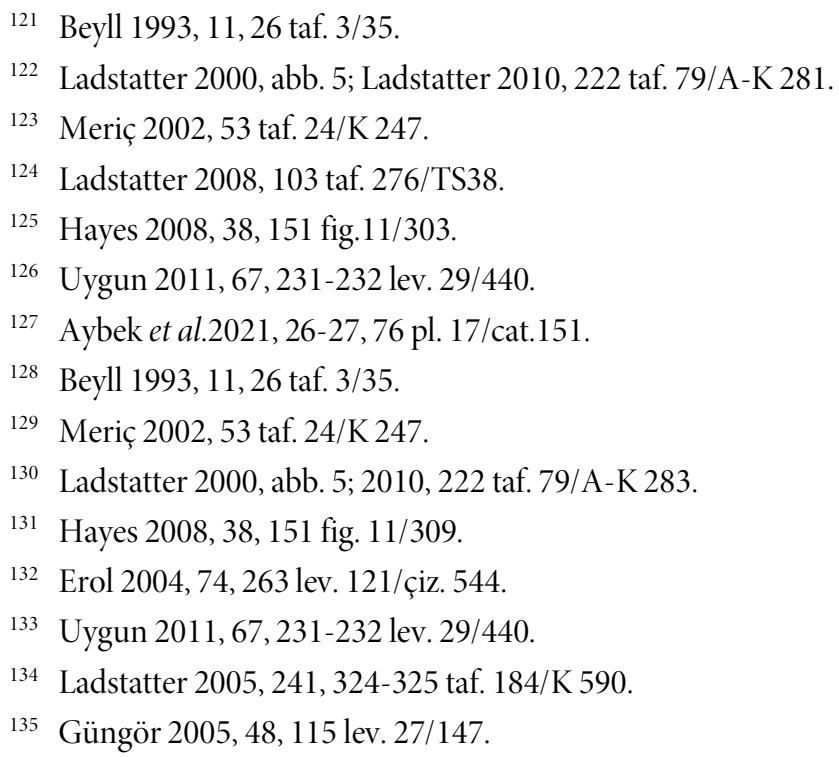


kontekste göre de MS 220-230 aralığına tarihlendirilmiştir ${ }^{136}$. Metropolis Aşağı Hamam Palaestra'da saptanan iki örneğin Metropolis örneklerinin bire bir benzerleri dışında Hayes Form 58 ile Labraunda' da ${ }^{137}$, Samos'ta ${ }^{138}$, Berenike'de ${ }^{139}$, Korinthos'ta ${ }^{140}, K^{1}$ nossos'ta ${ }^{141}$, Assos'ta ${ }^{142}$, Menderes Magnesiası'nda ${ }^{143}$, Aizanoi' da ${ }^{144}$ karşılaşılmıştır. Bu kadar popüler olan bir form gerek karşılaştırma örnekleri ışığında gerekse Hayes’ in önerisi doğrultusunda tarihlendirilebilir. Kat. No. 19-24 arasındakiörnekleri MS 75-125 aralı̆̆ına tarihlendirmek mümkündür. Formun yerel atölyelerde üretilen imitasyonu olan Kat. No. 25 ve 26 ise gerek astar, kil ve form özellikleri gerekse Ephesos'taki konteksten hareketle, MS III. yüzylın ilk yarısina tarihlendirilebilir.

\section{Mtr Aşağı Hamam Palaestra Form 12-Hayes Form 60 (Kat. No. 27-32; Fig. 20.1-6)}

İçe dönük ağız kenarlı, aşağıya sarkık dışbükey formlu dudakl1, konik gövdeli tabak formudur. Aşağı Hamam Palaestra'da bu forma ait altı örnek saptanmıştır. Kat. No. 27-28 ve Kat. No. 31-32 tam profil verirken Kat. No. 29-30 ağız kenarı-gövde parçasıdır. Bu form Hayes’ in DSB II tipolojisinde Form 60 grubuna girmektedir. Hayes, bu formu kenar profili ve cidar kalınlığına göre a ve b olmak üzere iki alt gruba ayırmıştır. "A" grubunu DSB I grubundaki Hayes Form 19 ile yakın benzerliğinden yola çıkarak MS 50/60 yıllarına tarihlemiştir. Cidar kalınlığının daha fazla olduğu ve "b" grubunda değerlendirdiği örnekleri ise MS 150 yllına tarihler ${ }^{145}$. Metropolis'te bu forma giren tabaklar da Hayes'in tipolojisine göre a ve b olmak üzere iki gruba ayrılmıştır. Kat. No. 27-30 a grubuna girerken, Kat. No. 31-32 b grubuna girmektedir. Hayes Form 60 tıpkı Hayes Form 58 gibi DSB II seramikleri arasında en yoğun bulunan formlardan birisidir. Așağı Hamam Palaestra'da bulunan ve a grubuna giren örneklerin yakın benzerleriyle Metropolis Peristilli Ev' $\mathrm{e}^{146} \mathrm{karşılaşılmıştır.} \mathrm{Bu} \mathrm{grubun} \mathrm{en} \mathrm{yoğun} \mathrm{bulun-}$ duğu merkezlerin başında ise Ephesos gelmektedir. Ephesos'ta Meryem Ana Kilisesi'nde ${ }^{147}$, Tetragonos Agorası Güney Kapısı’nda ${ }^{148}, 2$ numaralı Yamaç Ev'de ${ }^{149}$ ve Devlet Agorası Kuyu buluntuları ${ }^{150}$ arasında Metropolis tabaklarının benzerleri görülmektedir. Tralleis'te ise seramik bothrosu örnekleri iki ayrı form grubunda değerlendirilmiş ve kenar profillerine göre beş alt gruba ayrılmıştır. Bunların içinden geniş ağızlı ve derin olan tabaklar Ephesos karşılaştırma örneklerine dayanarak MS 150-250

\footnotetext{
136 Ladstatter 2005, 241, 324-325.

137 Hellström 1965, 34 pl. 35/214.

138 Unterkircher 1983, 184 taf. 4/11.2.

139 Kenrick 1985, 249 fig. 45/351.1-2.

140 Slane 1990, 49 fig. 6/92.

141 Sackett 1992, 157, 226 pl. 153/44, 156/10, 166/10a.

142 Zelle 1997, 49 abb. 9/71,73.

143 Vapur 2001, $17-18$ çiz. 1, 6-7; 2011, 151-152 çiz. 2/20-21; 2013, 643-644 çiz. 1/6-8; Eliüşük 2021, 21, 27 lev. 2-3, Kat. No. 10-11.

144 Ateş 2002, 328 abb. 2/10; Ateş 2015, 144-145 taf. 63/364-365.

145 Hayes 1985, 64; Uygun 2011, 68.

146 Aybek et al. 2021, 26-27, 76 pl. 17/cat.152, 29, 82 pl. 21/cat.198.

147 Beyll 1993, 26 taf. 3/40-41.

148 Gassner 1997, 132 taf. 43/507.

149 Ladstatter 2000, 100 abb. 6/2; Ladstatter \& Liedl 2020, 40 taf. 3/K 29.

150 Meriç 2002, 53-54, 62 taf. 25/K 260.
} 
yllarına tarihlendirilmiştir ${ }^{151}$. Formun diğer benzer örnekleri ise Atina Agorası'nda ${ }^{152}$, Korinthos'ta ${ }^{153}$, Samos'ta ${ }^{154}$, Anemurion'da ${ }^{155}$, Assos'ta ${ }^{156}$, Menderes Magnesiasi'nda ${ }^{157}$, Aizanoi' da ${ }^{158}$, Didyma' da $^{159}, \mathrm{~Pa}^{1}$ tara' ${ }^{\prime} a^{160}$ ve Andriake'de ${ }^{161}$ bulunmuştur. Kat. No. 31-32 ise b grubuna girmektedir. Bu örnekler Hayes Form 60’ in b grubunda değerlendirilmesine rağmen aralarında küçük farklar olması nedeniyle karşılaştırma örnekleri farklıdır. Kat. No. 31'in benzerleriyle Berenike'de ${ }^{162}$, Paphos'ta ${ }^{163}$, Ephesos'ta ${ }^{164}$, Elaiussa Sebaste' de ${ }^{165}$, Atina Agorası̉nda ${ }^{166}$ ve Metropolis Peristilli Ev' de ${ }^{167}$ karşılaşılmıştır. Kat. No. 32'nin benzerleri ise Knossos'ta ${ }^{168}$, Ephesos Tetragonos Agorası Güney Kapısı'nda ${ }^{169}$, Atina Agorası' nda ${ }^{170}$, Patara' da ${ }^{171}$ ve Metropolis' in Peristilli Ev ${ }^{172}$ ile Zeus Krezimos Kutsal Alanı ${ }^{173}$ gibi farklı çalışma alanlarında tespit edilmiştir. Birçok farklı coğrafyada ve farklı merkezde bulunması formun oldukça popüler olduğunu göstermektedir. Farklı merkezlerde form için önerilen tarih genellikle Hayes' in tarihlemesine paralel bir tarih aralığıdır. Hayes Form 60 a grubuna giren Kat. No. 27-30 MS I. yüzyılın ikinci yarısına, Hayes Form 60 b grubuna giren Kat. No. 31-32 MS II. yüzyılın ilk yarısına tarihlenebilir.

\section{Mtr Aşağı Hamam Palaestra Form 13-Hayes Form 70 (Kat. No. 33-44; Fig. 21.1-12)}

İçe dönük ağız kenarlı, sivri bitimli ve dikey dudaklı, dışa taşkın dirsek profilli, kaideye doğru daralan konik gövdeli ve alçak halka kaideli kâse formudur. Formun karakteristik özelliği dudak ve dirsek üzerinde rulet bezeme, kasenin tondosunda ise baskı olarak yapılmış rozet bezemelerinin olmasıdır. Așağı Hamam Palaestra'da en yoğun saptanan DSB formudur. Yapıda saptanan 12 örnekten Kat. No. 33-36

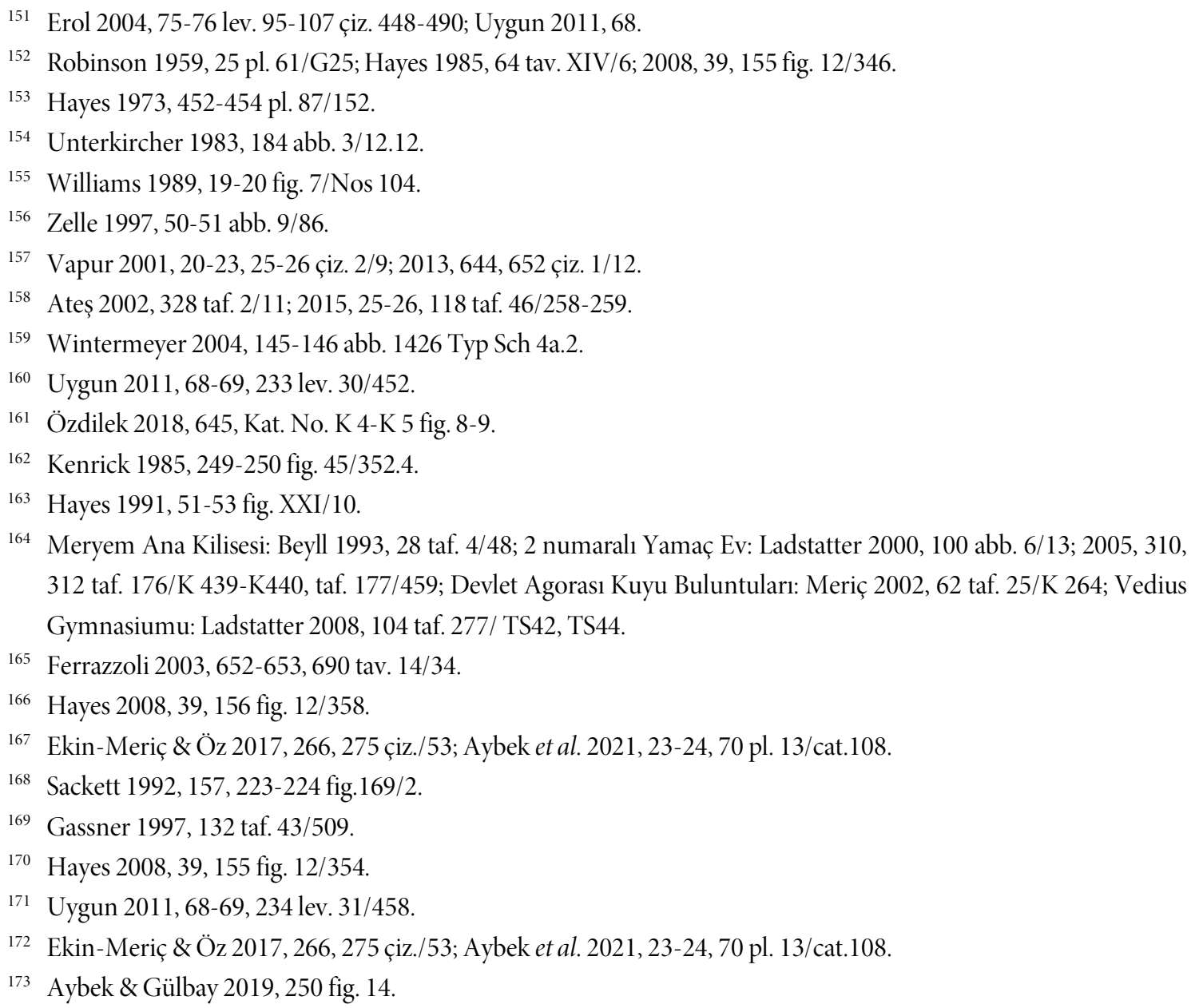


ağız kenarı-gövde parçası, Kat. No. 37-38 kaide-gövde parçası ve Kat. No. 39-44 ise tam profil veren örneklerdir. Mtr Aşağı Hamam Palaestra Form 13, form özellikleri açısından ele alındığında DSB 2 tipolojisinde Hayes Form 70 grubu içerisine girmektedir. Tipkı Hayes Form 58 ve 60 'ta olduğu gibi bu form da karşılaştırma örnekleri açısından oldukça zengindir. Ağız kenarı gövde parçası olan Kat. No. 33-36' nın benzerleri yoğun olarak Ephesos'ta tespit edilmiştir. Formun benzerleri Ephesos'ta Meryem Ana Kilisesi'nde ${ }^{174}$, Tetragonos Agorası Güney Kapısı'nda ${ }^{175}, 2$ numaralı Yamaç Ev'de ${ }^{176}$, Ephesos'ta Devlet Agorası Kuyu Buluntuları arasında ${ }^{177}$ ve Vedius Gymnasium’unda ${ }^{178}$ saptanmıştır. Metropolis’te ise Ada 7' $\mathrm{de}^{179}$, Zeus Krezimos Kutsal Alanı'nda ${ }^{180}$ ve Peristilli Ev' de ${ }^{181}$ formun benzerleri tespit edilmiştir. Ephesos ve Metropolis' in dışında formun benzerleri Atina Agorasinda ${ }^{182}$, Berenike'de ${ }^{183}$, Assos'ta ${ }^{184}$, Patara'da ${ }^{185}$, Menderes Magnesiasínda ${ }^{186}$ ve Andriake'de ${ }^{187}$ tespit edilmiștir. Kat. No. 34 ve 35 'in dudağının üzerinde rulet bezeme görülmektedir (bk. Fig. 7; 21.2-3). Kat. No. 37-38' in benzerleri Atina Agorasínda ${ }^{188}$, Ephesos 2 numaralı Yamaç Ev' de ${ }^{189}$, Metropolis Ada 7' de ${ }^{190}$, Laodikeia' da ${ }^{191}$, Patara' da ${ }^{192}$ ve Menderes Magnesiası' nda ${ }^{193}$ saptanmıştır. Kat. No. 37'nin ve Kat. No. 38 'in tondosunda baskı rozet bezemesi görülmektedir (bk. Fig. 7; 21.5-6). Kat. No. 39-44 arasındaki örnekler tam profil vermeleri açısından oldukça önemlidirler. Bu kaseler kısa ağız kenarlı, kenar profilinin kalın cidarlı olması, kasenin boyutlarının daha küçük olması ve dolayısıyla sığ olmalarıyla ortak özellikler göstermektedir. Ayrıca bu örneklerin astar kaliteleri de grubun diğer örneklerine göre oldukça kötüdür. Bu açıdan ele alındıklarında ise Hayes Form 70 ile genel özellikler açısından benzeşirken yukarıda ifade edilen özellikler açısından da farklıdırlar. Bu kaseler olasılıkla Hayes Form 70 ' in yerel atölyelerde üretilmiş imitasyonları olmalıdır. Kat. No. 39'un benzerleri Ephesos 2 numaralı Yamaç Ev’ de ${ }^{194}$, Vedius Gymnasium’unda ${ }^{195}$,

\footnotetext{
174 Beyll 1993, 26 taf. 3/28-29,31.

175 Gassner 1997, 133 taf. 43/515.

176 Ladstatter 2000, 98-99 abb. 5; 2005, 326 taf. 185/K 609; 2010, 225 taf. 81/A-K 310; Ladstatter \& Liedl 2020, 41 taf. 4/K 48.

177 Meriç 2002, 63 taf. 26/K275.

178 Ladstatter 2008, 105 taf. 278/TS58- TS59.

179 Güngör 2005, 110 lev. 22/113.

180 Aybek \& Gülbay 2019, 250 fig. 14.

181 Aybek et al. 2021, 23-24, 70 pl. 13/cat.109, 29, 82 pl. 21/cat.199.

182 Hayes 1985, 66-67 tav. XV/1; 2008, 157-158 fig. 13/381.

183 Kenrick 1985, 253-254 fig. 46/B 359.1-3.

184 Zelle 1997, 44-45, 178 abb. 8/45, 46, 50, 51.

185 Uygun 2011, 70-71, 235 lev. 31/468.

186 Vapur 2013, 654 çiz. 2/22.

187 Özdilek 2018, 646- 647, Kat. No. 4 fig. 6.

188 Hayes 1985, 66-67 tav. XV/1; 2008, 159 fig. 13/398.

189 Ladstatter 2000, 98-99 abb. 5; 2008, 106 taf. 278/TS67; 2010, 262 taf. 105/A-K 761-762; Ladstatter \& Liedl 2020, 41 taf. $4 / \mathrm{K} 50$

190 Güngör 2005, 110 lev. 22/118.

191 Şimşek et al. 2011, 116 lev. 103/360.

192 Uygun 2011, 70-71, 235 lev. 31/466.

193 Vapur 2013, 655-656 çiz. 2/29.

194 Ladstatter 2000, 98-99 abb. 5; 2010, 262 taf. 105/A-K 761.

195 Ladstatter 2008, 106 taf. 278/TS67.
} 
Metropolis Ada 7' de ${ }^{196}$, Patara' da ${ }^{197}$ ve Menderes Magnesiası'nda ${ }^{198}$ saptanmıştır. Ayrıca Kat. No. 39'un tondosunda baskı rozet bezeme görülmektedir (bk. Fig. 7; 21.7). Kat. No. 40-44'ün ise en yakın benzerleri Ephesos'ta 2 numaralı Yamaç Ev'de ${ }^{199}$ ve Menderes Magnesiası Artemis Kutsal Alanı Güney Stoa' $\mathrm{da}^{200}$ bulunmuștur. Ephesos örnekleri kontekste göre MS III. yüzyılın ilk yarısı ile MS III. yüzyılın 3.çeyreğine tarihlendirilirken ${ }^{201}$, Menderes Magnesiası örnekleri MS II. yüzyılın ikinci yarısı ile MS III. yüzyılın ilk yarısı arasına tarihlendirilmiştir ${ }^{202}$. Mtr Aşağı Hamam Palaestra Form 13 başlığında ele alınan 12 kaseyi oldukça geniş ve farklı coğrafyalardaki benzerleri doğrultusunda tarihlendirmek mümkündür. Bu bağlamda bakıldığında Kat. No. 33-38 arasındaki örnekler MS I. yüzyıl sonu ile MS II. yüzyıl başına Kat. No. 39-44 arasındaki kaseler ise özellikle Ephesos'taki kontekstlerden hareketle MS III. yüzylla tarihlendirilebilir.

\section{Mtr Așağı Hamam Palaestra Form 14-Hayes Form 74 a (Kat. No. 45; Fig. 22)}

Dışa uzantılı ağız kenarlı, aşağıya sarkık dudaklı, alçak kaideye doğru daralan konik gövdeli kase formudur. Metropolis Așağı Hamam Palaestra'da bu gruba giren tek örnek saptanmıştır. Kat. No. 45 ağız kenarı-gövde parçasıdır. Özellikle kenar özellikleri bakımından bu örnek Hayes Form 74 a grubunda değerlendirilmiştir. Hayes, Form 74 grubunu a ve b olmak üzere iki alt gruba ayırmıştır. Söz konusu kaseler form özellikleri açısından birbirine çok yakındır. Esas ayrım noktaları dudak yapısı ve kenar üzerindeki bezemelerdir. Hayes Form 74 a tıpkı Metropolis örneğinde olduğu gibi bezemesizdir. Hayes Form 74 b ise dudak üzerindeki rulet bezeme ile diğer gruptan ayrılmaktadır ${ }^{203}$. Formun yakın benzerleri Atina Agorası̉nda ${ }^{204}$ ve Patara' da ${ }^{205}$ saptanmıștır. Mtr Așağı Hamam Palaestra Form 14'ü gerek Hayes' in önerisi gerekse benzerlerinin yardımıyla MS I. yüzyıl sonu ile MS II. yüzyıl başına tarihlendirmek mümkündür.

\section{Mtr Aşağı Hamam Palaestra Form 15-Hayes Form 76 a (Kat. No. 46; Fig. 23)}

Dışa uzantılı ve düz ağız kenarlı, kaideye doğru daralan konik gövdeli, alçak halka kaideli kase formudur. Așağı Hamam Palaestra' da bu gruba giren bir ağız kenarı-gövde parçası saptanmıștır. Hayes Form 76 yı tıpkı bir önceki form gibi a ve b olmak üzere iki alt gruba ayırmıștır. Hayes Form 76 a, 7 $16 \mathrm{~cm}$ arasında ağız çapına sahiptir. Hayes Form 76 b’nin ağız çapı ise 16-30 cm'dir. Bu bağlamda bakıldığında iki alt grup arasındaki en belirgin fark kaselerin boyutlarıdır. Hayes Form 76 a daha küçük ve ince cidarlı bir kase iken Hayes Form 76 b daha derin ve daha büyük bir kasedir ${ }^{206}$. Metropolis kasesi bu özellikler açısından değerlendirildiğinde de 15,5 cm'lik ağız çapı ile Hayes Form 76 a grubuna girmektedir. Form özellikleri açısından bu küçük farkların yanı sıra bu kaselerin tarihleri de

196 Güngör 2005, 110 lev. 22/117.

197 Uygun 2011, 70-71, 235 lev. 31/466, 468.

198 Vapur 2013, 655-656 çiz. 2/26, 29.

199 Ladstatter 2005, 353-354 taf. 204/K 873.

200 Eliüşük 2021, 22-23, 28-29 lev. 4/19.

201 Ladstatter 2005, 260, 353-354.

202 Eliüşük 2021, 22-23, 28-29.

203 Hayes 1985, 68 tav. XV/6-7.

204 Hayes 2008, 39, 154 fig. 12/341-342.

205 Uygun 2011, 71-72, 236-237 lev. 32/477, 479.

206 Hayes 1985, 68-69 tav. XV/10. 
farklıdır. Hayes Form 76 a'yı MS I. yüzyılın ikinci yarısına tarihlerken Form 76 b'yi MS 100-150 aralığına tarihlemiştir ${ }^{207}$. Mtr Aşağ Hamam Palaestra Form 15 'in benzerleriyle Korinthos'ta ${ }^{208}$, Samos'ta ${ }^{209}$, Berenike'de ${ }^{210}$, Ephesos'ta Meryem Ana Evi'nde ${ }^{211}$ ve Devlet Agorası Kuyu Buluntular1 ${ }^{212}$ arasında, Atina Agorası'nda ${ }^{213}$ karşılaşılmıştır. Karşılaştırma örnekleri ışığında Mtr Aşağı Hamam Palaestra Form 15’i MS I. yüzyılın ikinci yarısına tarihlendirmek mümkündür.

\section{Mtr Așağı Hamam Palaestra Form 16-Hayes Form 78 (Kat. No. 47; Fig. 24)}

Dışa uzantılı ağız kenarlı, konik gövdeli, düz dipli kase formudur. Dudak üzerindeki yiv ve iç yüzde ağız kenarından gövdeye geçişteki profillendirme formun karakteristik özelliğidir. Metropolis Aşağı Hamam Palaestra' da bu forma giren ve tam profil veren tek örnek tespit edilmiştir. Metropolis örneğinin bire bir benzeri ne yazık ki henüz mevcut değildir. Metropolis kasesi özellikle ağız kenarı ve gövde özellikleri açısından Hayes Form 78 ile benzeşirken kaide özellikleri açısından bu formdan farklıdır. Metropolis örneğini Hayes Form 78'den ayıran bir başka özelliği de boyutlarıdır. Kat. No. 47, Hayes Form 78'e göre daha küçük ağız çapına sahiptir. Hayes, bu formun Form 77 ile bağlantılı olduğunu belirtir. Bazı örneklerin dudağı üzerinde rulet bezeme görülmektedir ${ }^{214}$. Hayes Form 78 nadir bulunan bir form olması nedeniyle karşılaştırma örnekleri de oldukça sınırlıdır. Genel form özellikleri açısından değerlendirildiğinde Mtr Așağı Hamam Palaestra Form 16, Hayes Form 78'in varyasyonu olmalıdır. Kat. No. 47'nin özellikle ağız kenar ve gövde formu açısından benzerleriyle Labraunda' $\mathrm{da}^{215}$, Atina Agorasi'nda ${ }^{216}$ ve Menderes Magnesiası'nda ${ }^{217}$ karşılaşılmıştır. Karşılaştırma örneklerinin tamamının ağız kenarı ve gövdeleri Metropolis örneği ile benzeşirken bu örneklerin tamamının kaidesi Metropolis örneğinden farklıdır. Hayes'in önerisi ve benzerleri yardımıyla Metropolis örneğini MS II. yüzyılın ilk yarısına tarihlendirmek mümkündür.

\section{Mtr Aşağı Hamam Palaestra Form 17-Hayes Form 80 (Kat. No. 48-50; Fig. 25.1-3)}

Dışa uzantılı ağız kenarlı, düz ve yatay dudaklı, yuvarlak gövdeli, alçak halka kaideli kase formudur. Kasenin tipik özelliği tondosunun merkezinde yer alan kademeli yivlerin olmasıdır. Metropolis Așağı Hamam Palaestra'da bu gruba giren üç örnek saptanmıştır. Kat. No. 48 tam profil verirken Kat. No. 49-50 ağız kenarı-gövde parçasıdır. Metropolis örneği bu üç kase genel form özellikleri açısından değerlendirildiğinde Hayes Form 80 grubu içerisine girmektedir ${ }^{218}$. Hayes, Form 80 'in özellikle tondosundaki yivler nedeniyle metal pateraların taklidi olduğunu belirtir. Ayrıca Hayes bu grubun geniş ya da dar olmak üzere iki gövde profili olduğunu söyler ${ }^{219}$. Formun karşlaştırma örnekleri oldukça geniş bir coğrafyada ve farklı merkezlerde saptanmıştır. Hatta öyle ki Antiokheia'da bu formun yerel atölyelerde

207 Hayes 1985, 68-69.

208 Hayes 1973, 454 pl. 87/154.

209 Unterkircher 1983, 187-188 abb. 5/21.5.

210 Kenrick 1985, 254 fig. 46/361.3.

211 Beyll 1993, 24 taf. 2/19.

212 Meriç 2002, 63 taf. 26/K 285.

213 Hayes 2008, 40, 160 fig. 13/421.

214 Hayes 1985, 69.

215 Hellström 1965, 70 pl. 36/248.

216 Robinson 1959, 27 pl. 65/G50; Hayes 2008, 40, 160 fig. 13/419-420.

217 Vapur 2011, 154 çiz. 3/30-31.

218 Hayes 1985, 69-70 tav. XV/15.

219 Hayes 1985, 69-70. 
üretildiği tespit edilmiştir ${ }^{220}$. Bu durum formun oldukça popüler olduğunu göstermektedir. Mtr Așağı Hamam Palaestra Form 17'nin benzerleri ile Antiokheia'da ${ }^{221}$, Atina Agorasi'nda ${ }^{222}$, Berenike'de ${ }^{223}$, Korinthos'ta ${ }^{224}$, Paphos'ta ${ }^{225}$, Knossos'ta ${ }^{226}$, Ephesos'ta Meryem Ana Evi'nde ${ }^{227}$, Tetragonos Agoras1 Güney Kapısinnda ${ }^{228}, 2$ numaralı Yamaç Ev'de ${ }^{229}$, Vedius Gymnasiumu’nda ${ }^{230}$, Tralleis'de ${ }^{231}$, Patara' $\mathrm{da}^{232}$ ve Menderes Magnesiasínın farklı çalışma alanlarında ${ }^{233}$ karşılaşılmıştır. Metropolis örneği üç kase karşılaștırma örneklerinin yardımıyla MS I. yüzyıl sonu ile MS II. yüzyılın ilk yarısı arasına tarihlendirilebilir.

\section{Sonuç}

Bu çalışmada değerlendirilen DSB grubuna giren seramik örnekleri Metropolis’te Aşağı Hamam Palaestra'da gerçekleştirilen kazılar sonucunda ele geçmiştir. Aşağı Hamam Palaestra'da 2003-2006, 2009-2019 yıllarında aralıklarla gerçekleștirilen kazılar sonucunda DSB grubuna giren 127 örnek tespit edilmiştir. Bu örneklerden 50'si bu çalışmada değerlendirilmiştir. Bu grup içinde 17 form saptanmıştır. DSB 1 ve DSB 2 grubunda ele alınan bu örnekler tabak ve kaselerden oluşmaktadır. DSB 1 grubuna giren 12 örnek saptanırken DSB 2 grubunda 38 örnek saptanmıştır. DSB 1 ve DSB 2 grubundaki form yoğunlukları da farklıdır. DSB 1 grubunda en yoğun form 3 örnekle Mtr Aşağı Hamam Palaestra Form 2'dir (Hayes Form 23). Bu örneği ikişer örnekle Mtr Aşağı Hamam Palaestra Form 5 ve 6 (Hayes Form 28 ve 29) izler. Diğer formların ise birer örneği saptanmıştır. DSB 2 grubunda 12 örnekle Mtr Aşağı Hamam Palaestra Form 13 (Hayes Form 70) en yoğun formdur. Bu formu 8 örnekle Mtr Aşağı Hamam Palaestra Form 11 (Hayes Form 58), 6 örnekle Mtr Aşağı Hamam Palaestra Form 12 (Hayes Form 60), 4 örnekle Mtr Aşağı Hamam Paleastra Form 10 (Hayes Form 55), 3 örnekle Mtr Aşağı Hamam Palaestra Form 17 (Hayes Form 80) ve 2 örnekle Mtr Aşağı Hamam Palaestra Form 9 (Hayes Form 53) izler. Diğer form gruplarının ise birer örneği saptanmıştır (bk. Fig. 6).

DSB 1 grubunda ele alınan tüm örnekler MS I. yüzyılın ilk yarısına tarihlendirilmektedir. DSB 2 grubunda ise en erken formlar MS I. yüzyılın ikinci yarısına tarihlenen Mtr Aşağı Hamam Palaestra Form 9-10, 12 ve 15’tir. En geç tarihli DSB2 örnekleri ise MS III. yüzylla tarihlenen Mtr Aşağı Hamam Palaestra Form 11 ve 13 'tür. MS III. yüzyıla tarihlenen DSB'lerin ortak iki noktası görülmektedir. Bunlardan ilki hem Mtr Aşağı Hamam Palaestra Form 11'de hem de 13 grubundaki geç formların imitasyon olmalarıdır. İkincisi ise bu gruplara dahil edilen örneklerin karşılaşıırma örneklerinin Ephesos kökenli olmasıdır. Dolayısılla bu grupların tarihleme önerisi Ephesos örneklerinin kontekstlerine göre yapılmıştır.

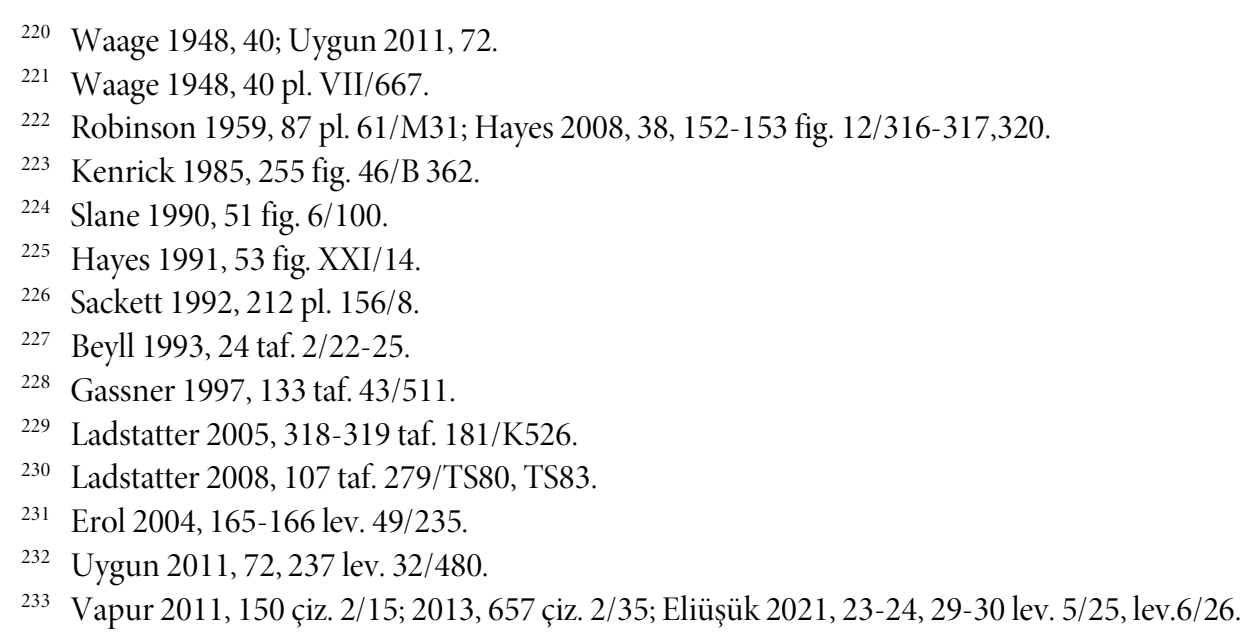


Katalogdaki DSB'ler hamur ve astar renkleri açısından da DSB 1 ve DSB 2 olarak iki alt grupta ele alınmıştır. DSB 1 örnekleri hamur ve astar renkleri açısından değerlendirildiğinde, bu örneklerin hamurunun rengi kırmızının farklı tonlarındadır. Genellikle gümüş mika katkılı, sıkı, gözeneksiz ve sert pişimli kaliteli bir hamur dokusu görülmektedir. Gruptaki örnekler Munsell renk kataloğuna göre 8 farklı hamur rengine sahiptir. Munsell kataloğundaki karşılığ 2,5 YR 4/8, 5/8, 6/6, 6/8, 7/8, 5 YR 4/6, 6/8, 10 R 6/8'dir. Astarı ise daldırma tekniğinde uygulanmıştır. Astar mat ve hafif sabunumsudur. Ayrıca kırmızıdan portakal rengine kadar değişkenlik gösterir. Grupta yer alan örneklerde Munsell renk kataloğuna göre 5 farklı astar rengi saptanmıştır. Astar renginin Munsell kataloğundaki karşıllı̆̆ 2,5 YR 4/6, 4/8, 5/8, 10 R 5/6, 5/8'dir. DSB 2 örnekleri hamur ve astar özellikleri açısından ele alınd1ğında ise örneklerin hamur rengi genellikle DSB 1 grubundaki hamur renklerine benzemektedir. Bazen birkaç ton daha koyu hamur rengi görülmektedir. Hamur yoğun gümüş mika katkılıdır. Katmanlaşmış hamur yapısı en belirgin özellik olarak dikkat çekmektedir. Gruptaki örnekler Munsell renk kataloğuna göre 11 farklı hamur rengine sahiptir. Bu renklerin Munsell kataloğundaki karşllı̆̆ 2,5 YR 4/6, 5/6, 5/8, 6/6, 6/8, 7/4, 7/8, 5 YR 5/6, 6/8, 10 R 5/8 ve 6/6'dır. Astar rengi, portakalımsı kırmızı gibi açık tonlardadır. Bu gruba dahil edilen örneklerin profil birleşme yerlerinde, astar daha yoğun olduğu için, ince çatlaklar oluşmaktadır. Ayrıca bu grupta yine bazı formların yerel varyasyonlarında kırmızı rengin farklı tonları da mevcuttur. Grupta yer alan örneklerde Munsell renk kataloğuna göre 5 farklı astar rengi saptanmıştır. Astar renginin Munsell kataloğundaki karşılığı 2,5 YR 4/8, 5/8, 10 R $4 / 8,5 / 6$ ve $5 / 8$ 'dir.

DSB’lerin genel özellikleri arasında görülen baskı bezemeler Metropolis Aşağı Hamam Palaestra DSB'lerinde de benzer şekilde tespit edilmiştir. DSB 1 ve DSB 2 örnekleri arasında bezeme özelliklerinin farklı olduğu görülmektedir. DSB 1 grubunda yer alan Mtr Aşağı Hamam Palaestra Form 2 grubundan (Hayes Form 23) bir kaidenin tondosunda çömlekçi ismi olan "EPMH $\Sigma$ ” baskısı saptanmıştır. Bu tür baskılarla genellikle DSB 1 grubunda karşılaşılmaktadır. DSB 2 grubunda yer alan seramiklerde ise genellikle seramiklerin ağız kenarı, dudak ve dirsek gibi bölümlerinde rulet bezemeler ön plandadır. DSB’lerin tondolarında rulet bezeme görülmesine karşın Aşağı Hamam Palaestra DSB'lerinin tondolarında rulet bezeme görülmez. DSB 2 grubundaki kase ve tabakların tondolarında rozet bezeme örnekleriyle karşılaşılmıştır (bk. Fig. 7).

\begin{tabular}{|c|c|c|c|c|c|}
\hline $\begin{array}{l}\text { Kat. No./ } \\
\text { Fig. No. }\end{array}$ & $\begin{array}{c}\text { Ağız Kenarı/ } \\
\text { Dudak Bezemeleri }\end{array}$ & $\begin{array}{l}\text { Kat. No./ } \\
\text { Fig. No. }\end{array}$ & $\begin{array}{c}\text { Dirsek } \\
\text { Bezemeleri }\end{array}$ & $\begin{array}{l}\text { Kat. No. / Fig. } \\
\text { No. }\end{array}$ & $\begin{array}{c}\text { Tondo } \\
\text { Bezemeleri }\end{array}$ \\
\hline $\begin{array}{l}\text { Kat. No. } 21 \text { / } \\
\text { Fig. No. } 19.3\end{array}$ & & $\begin{array}{c}\text { Kat. No. } 21 \\
\text { / Fig. No. } \\
19.3\end{array}$ & & $\begin{array}{c}\text { Kat. No. } 3 \text { / } \\
\text { Fig. No. } 10.2\end{array}$ & EPMHS \\
\hline $\begin{array}{l}\text { Kat. No. 34 / } \\
\text { Fig. No. } 21.2\end{array}$ & & $\begin{array}{c}\text { Kat. No. } 36 \\
\text { / Fig. No. } \\
21.4\end{array}$ & & $\begin{array}{l}\text { Kat. No. } 24 \text { / } \\
\text { Fig. No. } 19.6\end{array}$ & \\
\hline \multirow[t]{3}{*}{$\begin{array}{l}\text { Kat. No. 35/ } \\
\text { Fig. No. } 21.3\end{array}$} & & & & $\begin{array}{l}\text { Kat. No. } 37 \text { / } \\
\text { Fig. No. } 21.5\end{array}$ & 80 \\
\hline & & & & $\begin{array}{l}\text { Kat. No. } 38 / \\
\text { Fig. No. } 21.6\end{array}$ & 88 \\
\hline & & & & $\begin{array}{l}\text { Kat. No. } 39 \text { / } \\
\text { Fig. No. } 21.7\end{array}$ & 80 \\
\hline
\end{tabular}

Fig. 7. Așağı Hamam Palaestra DSB'lerinin Damga ve Bezemeleri 
Aşağı Hamam Palaestra’ nın mimari olarak farklı dönemlerde değişiklikler geçirdiği ve elde edilen veriler sonucunda 3 evreli bir yapı olduğu saptanmıștır. Portikolara ait arşitrav blokları üzerindeki yazıt, yapının imparator Antoninus Pius (MS 138-161) zamanında inşa edildiğini göstermektedir. Yapının ilk evrede küçük bir yapı olduğu, yapıda değişikliğin ve asıl büyütmenin yapıldığı evrenin de Antoninus Pius zamanında olduğu tespit edilmiştir. Yapının son evresi olan 3. evrede MS IV. yüzyıl ve sonrası olarak yorumlanmıştır ${ }^{234}$. Yapıda bulunan ve bu çalışmada değerlendirilen DSB'lerin bu süreçteki dağılımına bakıldığında ise MS I. ve II. yüzyılda yoğun olduklarını MS III. yüzyılda ise DSB sayısının oldukça azaldığını görmekteyiz (bk. Fig. 8). Bu tarihsel dağılım tabii ki birçok merkezde görülen DSB yoğunluğuyla da bir paralellik göstermektedir.

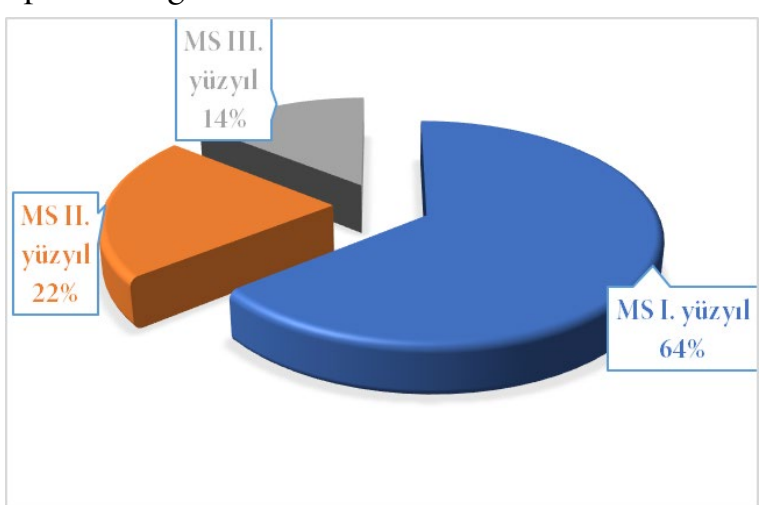

Fig. 8. Așağı Hamam Palaestra DSB’lerinin Yüzyllara Göre Dağılımı

Aşağı Hamam Palaestra' da ele geçen DSB'lerin değerlendirmesiyle elde edilen önemli sonuçlardan bir diğeri de DSB 2 grubundaki varyasyon ya da imitasyonların tespit edilmesidir. Bu bağlamda bakıldığında Mtr Așağı Hamam Palaestra Form 10 (Kat. No. 18) ve 16 (Kat. No. 47) örneklerinde varyasyonlar, Form 11 (Kat. No. 25-26) ve 13 (Kat. No. 39-44) gruplarına dahil edilen tabak ve kaseler arasında ise imitasyonlar görülmektedir. DSB üretim merkezleri arasında anılan Tralleis ve Ephesos gibi merkezlere oldukça yakın olan Metropolis'te formlarda görülen bu çeşitliliğin olması oldukça doğaldır. Aşağı Hamam Palaestra' da saptanan DSB örnekleri gerek nicelik açısından gerekse nitelik bakımından oldukça önemli bir gruptur. Bu grup Metropolis’te MS I. yüzyıl ile MS III. yüzyıl arasında DSB grubunun birçok farklı formunun, varyasyonların ve bazı formların imitasyonlarının varlığını göstermektedir. Ayrıca Hayes Form 58 ve 70 grubuna giren bazı imitasyonlar sayesinde grubun şimdiye kadar kabul gören tarihten daha geç bir tarihe MS III. yüzyıla tarihlendirilmesi ile de bazı formlarda görülen form farklılıkları ve formlardaki boyut, derinlik ile cidar kalınlığı gibi yapısal farklılıkların yanı sıra hamur ve astar kalitesinin de göz ardı edilmemesi gereken unsurlar olduğunu göstermesi açısından oldukça önemlidir.

234 Aybek 2016, 117-118. 


\section{Katalog}

(Katalogda kullanılan kısaltmalar; Kat. No: Katalog Numarası, Yük: Yükseklik, A.Çapı: Ağız Çapı, K.Çapı: Kaide Çapı, Cid. Kal: Cidar Kalınlığı.

DSB-1

Kat. No. 1 (Fig. 9)

Envanter No: 57-HY-13-18 Form No: Mtr Aşağ Hamam Palaestra Form 1 (DSB 1- Hayes Form 5) Form: Tabak Buluntu Yeri ve Seviyesi: Aşağı Hamam kuzeyi 37 (J -8) plan karesi- 50,13 m -49,21m Buluntu Tarihi: 13.08 .2013 Ölçüler: Y: 2,3 cm; A.Ç: 15,8 cm Hamur: 2,5 YR 5/8 (kırmızı) Astar: 2,5 YR 4/8 (kırmızı) Benzerleri: Hayes 1985, 54 tav. XI/14; Gassner 1997, 127 taf. 42/495; Mitsopoulos-Leon 1991, 100-101 taf. 120/H25; Meriç 2002, 49-51 taf. 20/K 183; Ladstatter 2000, abb. 5; Hayes 2008, 142 fig. 8/200; Ladstatter 2008, 101 taf. 275/TS 10; Uygun 2011, 48, 219 lev. 24/344. Tarih: MS I. yüzyılın ilk yarisi.

Kat. No. 2 (Fig. 10.1)

Envanter No: 480-HY-11-50 Form No: Mtr Aşağ Hamam Palaestra Form 2 (DSB 1- Hayes Form 23) Form: Kase Buluntu Yeri ve Seviyesi: U-19 plan karesi 42,30 m-41,59 m Buluntu Tarihi: 13.07.2011 Ölçüler: Y: 4,2 cm; A.Ç: 22,2 cm Hamur: 5 YR 4/6 (sarımsı kırmızı) Astar: 10 R 5/6 (kırmızı) Benzerleri: Hayes 1985, 57-58 tav. XII/18; Beyll 1993, 10 taf. 2/16; Zelle 1997, 52-53 abb. 10/96-97. Tarih: MS I. yüzyılın ilk yarısı.

Kat. No. 3 (Fig. 10.2)

Envanter No: 24-HY-04-93 Form No: Mtr Aşağı Hamam Palaestra Form 2 (DSB 1- Hayes Form 23) Form: Kase Buluntu Yeri ve Seviyesi: F 16/G 16 plan kareleri 3. İle 4. Fil ayağının arası, 46,40 m-45,35 m Buluntu Tarihi: 14.09.2004 Ölçüler: Y: 1,2 cm; K.Ç: 4,4 cm Hamur: 2,5 YR 6/8 (açık kırmızı) Astar: 2,5 YR 4/8 (kırmızı) Benzerleri: Hayes 1985, 57/58 tav. XII/18; Hayes 2008, 145 fig. 8/231. Tarih: MS I. yüzyılın ilk yarısı.

Kat. No. 4 (Fig. 10.3)

Envanter No: 57-HY-10-66 Form No: Mtr Aşağ Hamam Palaestra Form 2 (DSB 1- Hayes Form 23) Form: Kase Buluntu Yeri ve Seviyesi: Palaestra hamam önü giriş güneyi K-15/L-15 plan kareleri, 44,63 m-43,15 m Buluntu Tarihi: 09.08.2010 Ölçüler: Y: 1,5 cm; K.Ç: 8,4 cm Hamur: 5 YR 6/8 (kırmızımsı sar1) Astar: 2,5 YR 4/8 (kırmızı) Benzerleri: Hayes 1985, 57/58 tav. XII/18; Meriç 2002, 64 taf. 27/K 295; Uygun 2011, 57, 225 lev. 26/393. Tarih: MS I. yüzy1lın ilk yarısı.

\section{Kat. No. 5 (Fig. 11)}

Envanter No: 58-HY-13-27 Form No: Mtr Aşağ Hamam Palaestra Form 3 (DSB 1- Hayes Form 24) Form: Kase Buluntu Yeri ve Seviyesi: 49(A-7) plan karesi HY kuzeyi, 49,67 m-48,40 m Buluntu Tarihi: 22.08.2013 Ölçüler: Y: 1,8 cm; K. Ç: 11,6 cm Hamur: 2,5 YR 4/8 (kırmızı)Astar: 2,5 YR 4/6 (kırmızı) Benzerleri: Hayes 1973, 454 pl. 86/143; Hayes 1985, 58 tav. XII/19; Meriç 2002, 51 taf. 23/K 221-K222. Tarih: MS I. yüzyılın ilk yarısı.

Kat. No. 6 (Fig. 12)

Envanter No: 50-HY-13-34 Form No: Mtr Aşağ Hamam Palaestra Form 4 (DSB 1- Hayes Form 27) Form: Kase Buluntu Yeri ve Seviyesi: Așağı hamam kuzey batısı 49 (A 8/7) plan kareleri, 48,95 m-46,68 m Buluntu Tarihi: 27.08.2013 Ölçüler: Y: 3,1cm; K.Ç: 4,6 cm Hamur: 10 R 6/8 (açık kırmızı) Astar: 10 R 5/8 (kırmızı) Benzerleri: Hayes 1985, 58 tav.XII/23; Uygun 2011, 58, 226 lev. 27/402. Tarih: MS I. yüzy1lin ilk yarısı.

Kat. No. 7 (Fig. 13.1)

Envanter No: 84-HY-11-16 Form No: Mtr Aşağı Hamam Palaestra Form 5 (DSB 1- Hayes Form 28) Form: Kase Buluntu Yeri ve Seviyesi: T-15 plan karesi 42,55 m-41,64 m Buluntu Tarihi: 05.07.20110̈lçüler: Y: 1,9 cm; K. Ç: 14,4 cm Hamur: 2,5 YR 7/8 (açık kırmızı) Astar: 2,5 YR 5/8 (kırmızı) Benzerleri: Hayes 1985, 58 tav. XII/24; Hayes 2008, 148-149 fig. 10/275; Uygun 201 1, 58, 226 lev. 27/401; Ladstatter \& Liedl 2020, 42 taf. 69/K 55. Tarih: MS I. yüzyılın ilk yarısı.

Kat. No. 8 (Fig. 13.2)

Envanter No: 77-HY-10-89 Form No: Mtr Aşağ Hamam Palaestra Form 5 (DSB 1- Hayes Form 28) Form: Kase Buluntu Yeri ve Seviyesi: Palaestra hamam önü girişi K-15 plan karesi, 44,85 m-42,39 m Buluntu Tarihi: 17.08.10 Ölçüler: Y: 1,8 cm; K.Ç: 8,4 cm Hamur: 2,5 YR 6/6 (açık kırmızı) Astar: 2,5 YR 
5/8 (kırmızı) Benzerleri: Hayes 1985, 58 tav. XII/25; Hayes 2008, 148 fig. 10/271. Tarih: MS I. yüzyılın ilk yarısı.

\section{Kat. No. 9 (Fig. 14.1)}

Envanter No: 25-HY-16-07 Form No: Mtr Aşağ Hamam Palaestra Form 6 (DSB 1- Hayes Form 29) Form: Kase Buluntu Yeri ve Seviyesi: 49 A-6/7 batı servis koridoru, 47,40 m-46,20 m Buluntu Tarihi: 18.08.2016 Ölçüler: Y: 1,5 cm; K.Ç: 4,6 cm Hamur: 2,5 YR 6/6 (açık kırmızı) Astar: 2,5 YR 4/8 (kırmızı) Benzerleri: Hayes 1985, 59 tav. XII/26; Meriç 2002, 51-52, 60 taf. 23/K 228; Şimşek et al. 2011, 115 lev. 103/358; Uygun 2011, 57, 225-226 lev. 27/395; Aybek et al. 2021, 26-27, 76 pl. 17/cat.149. Tarih: MS I. yüzyılın ilk yarısı.

Kat. No. 10 (Fig. 14.2)

Envanter No: 39-HY-15-27 Form No: Mtr Aşağ1 Hamam Palaestra Form 6 (DSB 1- Hayes Form 29) Form: Kase Buluntu Yeri ve Seviyesi: 49 G-H/6 plan karesi Batı servis koridoru girişi, 49,01 m-47,42 m Buluntu Tarihi: 26.08.2015 Ölçüler: Y: 1,8 cm; K.Ç: 7,2 cm Hamur: 2,5 YR 5/8 (kırmızı) Astar: 2,5 YR 4/8 (kırmızı) Benzerleri: Hayes 1985, 59 tav. XII/27; Meriç 2002, 51-52, 60 taf. 23/K 227; Uygun 2011, 57, 226 lev. 27/397. Tarih: MS I. yüzyılın ilk yarısı.

\section{Kat. No. 11 (Fig. 15)}

Envanter No: 47-HY-13-20 Form No: Mtr Aşağ Hamam Palaestra Form 7 (DSB 1- Hayes Form 34) Form: Kase Buluntu Yeri ve Seviyesi: Aşağı hamam kuzeyi 37 (J- 8) plan karesi, 49,21 m-48,05 m Buluntu Tarihi: 14.08.2013 Ölçüler: Y: $5 \mathrm{~cm}$; K.Ç: $8 \mathrm{~cm} \mathrm{Ha}$ mur: 2,5 YR 6/8 (açık kırmızı) Astar: 2,5 YR 4/8 (kırmızı) Benzerleri: Hayes 1985, 60 tav. XIII/4; Erol 2004, 64, 209 lev. 80/380. Tarih: MS I. yüzyılın ilk yarisi.

\section{Kat. No. 12 (Fig. 16)}

Envanter No: 85-HY-10-58 Form No: Mtr Aşağ Hamam Palaestra Form 8 (DSB 1- Hayes Form 36) Form: Kase Buluntu Yeri ve Seviyesi: Palaestra hamam önü giriş güneyi, K-16 plan karesi, 44,78m43,31m Buluntu Tarihi: 04.08.2010 Ölçüler: Y: 3,6 cm; K.Ç: 5,4 cm Hamur: 2,5 YR 6/8 (açık kırmızı) Astar: 2,5 YR 4/8 (kırmızi) Benzerleri: Heberdey 1906, 173/52; Hayes 1985, 60 tav. XIII/6. Tarih: MS I. yüzyılın ilk yarısı.

\section{DSB-2}

Kat. No. 13 (Fig. 17.1)

Envanter No: 5-HY-14-75 Form No: Mtr Aşağı Hamam Palaestra Form 9 (DSB 2- Hayes Form 53) Form: Tabak Buluntu Yeri ve Seviyesi: 37 (I-9, H-9) plan karesi 2x10 metrelik alan düzenleme çalışması, 48,92 m-48,09 m Buluntu Tarihi: 24.10.2014 Ölçüler: Y: 3,1 cm; A.Ç: 12,9 cm; K.Ç: 7,8 cm Hamur: 2,5 YR 5/8 (kırmızı) Astar: 2,5 YR 4/8 (kırmızı) Benzerleri: Waage 1948, 38 pl. VI/S2; Jones 1950, 253 fig. 147/555, Fig. 197/555; Sackett 1992, 157 pl. 156/9; Hayes 1985, 62 tav. XIII/16; Erol 2004, 71-72 lev. 92/433; Uygun 2011, 66, 231 lev. 29/434; Ladstatter \& Liedl 2020, 25-26, 38 taf. 2/K 14. Tarih: MS I. yüzyılın ikinci yarısı.

Kat. No. 14 (Fig. 17.2)

Envanter No: 60-HY-10-89 Form No: Mtr Aşağı Hamam Palaestra Form 9 (DSB 2- Hayes Form 53) Form: Tabak Buluntu Yeri ve Seviyesi: Palaestra hamam önü girişi K-15 plan karesi, 44,85 m-42,39 m Buluntu Tarihi: 17.08.2010 Ölçüler: Y: 2,3 cm; K.Ç: 9,4 cm Hamur: 2,5 YR 6/8 (açık kırmızı) Astar: 2,5 YR 4/8 (kırmızı) Benzerleri: Waage 1948, 38 pl. VI/S2; Jones 1950, 253 fig. 147/555, fig. 197/555; Sackett 1992, 157 pl. 156/9; Hayes 1985, 62 tav. XIII/16; Erol 2004, 71-72 lev. 92/433; Uygun 2011, 66, 231 lev. 29/434; Ladstatter \& Liedl 2020, 25-26, 38 taf. 2/K 14. Tarih: MS I. yüzyılın ikinci yarısı.

Kat. No. 15 (Fig. 18.1)

Envanter No: 101-HY-12-06 Form No: Mtr Aşağ Hamam Palaestra Form 10 (DSB 2- Hayes Form 55) Form: Tabak Buluntu Yeri ve Seviyesi: Palaestra N24 plan karesi, 43,87 m-43,16 m Buluntu Tarihi: 09.07.2012 Ölçüler: Y: $3 \mathrm{~cm}$; A.Ç: 11,9 cm Hamur: 5 YR 6/8 (kırmızımsı sarı) Astar: 2,5 YR 5/8 (kırmızı) Benzerleri: Hayes 1985, 62 tav. XIII/18; Gassner 1997, 133, Taf.43/512; Uygun 2011, 66, 231 lev. 29/436. Tarih: MS I. yüzyılın ikinci yarısı.

Kat. No. 16 (Fig. 18.2)

Envanter No: 103-HY-12-16 Form No: Mtr Aşağ1 Hamam Palaestra Form 10 (DSB 2- Hayes Form 55) Form: Tabak Buluntu Yeri ve Seviyesi: Palaestra N26 plan karesi, 44,65 m-43,53 m Buluntu Tarihi: 13.07.2012 Ölçüler: Y: 3,6 cm; A.Ç: 18,8 cm Hamur: 2,5 YR 6/8(açık kırmızı) Astar: 2,5 YR 5/8 (kırmızı) Benzerleri: Hayes 1985, 62 tav. XIII/18; Gassner 
1997, 133 taf. 43/512; Uygun 2011, 66, 231 lev. 29/436. Tarih: MS I. yüzyılın ikinci yarısı.

Kat. No. 17 (Fig. 18.3)

Envanter No: 104-HY-12-06 Form No: Mtr Aşağ Hamam Palaestra Form 10 (DSB 2- Hayes Form 55) Form: Tabak Buluntu Yeri ve Seviyesi: Palaestra N24 plan karesi, 43,87 m-43,16 m Buluntu Tarihi: 09.07.2012 Ölçüler: Y: 3,3 cm; A.Ç: 14,2 cm Hamur: 2,5 YR 6/8(açık kırmızı) Astar: 2,5 YR 5/8 (kırmızı) Benzerleri: Hayes 1985, 62 tav. XIII/18; Gassner 1997, 133 taf. 43/512; Uygun 2011, 66, 231 lev. 29/436. Tarih: MS I. yüzyılın ikinci yarıs1.

Kat. No. 18 (Fig. 18.4)

Envanter No: 029-HY-09-94 Form No: Mtr Aşağı Hamam Palaestra Form 10 (DSB 2- Hayes Form 55) Form: Tabak Buluntu Yeri ve Seviyesi: M-18 plan karesi, 43,77 m-41,54 m Buluntu Tarihi: 17.08.2009 Ölçüler: Y: 1,7 cm; A.Ç: $15 \mathrm{~cm}$; K.Ç: $11 \mathrm{~cm}$ Hamur: 2,5 YR 6/8 (açık kırmızı) Astar: 2,5 YR 5/8 (kırmızı) Benzerleri: Ladstatter 2005, 240, 318 taf. 180/K 521; Hayes 2008, 40, 155 fig. 12/344; Ladstatter 2010, 178, 214 taf. 76/A-K 191. Tarih: MS II. yüzy1l

Kat. No. 19 (Fig. 19.1)

Envanter No: 35-HY-15-21 Form No: Mtr Aşağı Hamam Palaestra Form 11 (DSB 2- Hayes Form 58) Form: Tabak Buluntu Yeri ve Seviyesi: 49 (H-6 ) plan karesi, batı servis koridoru girişi, 48,92 m-47,93 m Buluntu Tarihi: 17.08.2015 Ölçüler: Y: 2,6 cm; A.Ç: 14,4 cm Hamur: 2,5 YR 6/6 (açık kırmızı) Astar: 10 R 4/8 (kırmızı) Benzerleri: Hayes 1985, 63 tav. XIV/3; Beyll 1993, 11, 26 taf. 3/35; Ladstatter 2000, abb. 5; Meriç 2002, 53 taf. 24/K 247; Hayes 2008, 38, 151 fig. 11/303; Ladstatter 2008, 103 taf. 276/TS29; Ladstatter 2010, 222 taf. 79/A-K 281; Uygun 2011, 67, 231-232 lev. 29/440. Tarih: MS 75-125.

Kat. No. 20 (Fig. 19.2)

Envanter No: 53-HY-13-60 Form No: Mtr Aşağ Hamam Palaestra Form 11 (DSB 2- Hayes Form 58) Form: Tabak Buluntu Yeri ve Seviyesi: 49 ( G-8, G9) plan karesi, güney servis koridoru tonoz içi, 47,44 m-44,69 m Buluntu Tarihi: 01,10.2013 Ölçüler: Y: 2,9 cm; A.Ç: 14,2 cm Hamur: 2,5 YR 5/8 (kırmızı) Astar: 10 R 5/8 (kırmızı) Benzerleri: Hayes 1985, 63 tav. XIV/3; Beyll 1993, 11, 26 taf. 3/35; Ladstatter 2000, abb. 5; Meriç 2002, 53 taf. 24/K 247; Hayes 2008, 38, 151 fig. 11/303; Ladstatter 2008, 103 taf.
276/TS29; Ladstatter 2010, 222 taf. 79/A-K 281; Uygun 2011, 67, 231-232 lev. 29/440. Tarih: MS 75-125.

Kat. No. 21 (Fig. 19.3)

Envanter No: 63-HY-10-107 Form No: Mtr Aşağı Hamam Palaestra Form 11 (DSB 2- Hayes Form 58) Form: Tabak Buluntu Yeri ve Seviyesi: Palaestra hamam önü kuzey, K-19, K-20 plan kareleri, 43,70 m43,20m Buluntu Tarihi: 27.08.2010 Ölçüler: Y: 2,7 cm; A.Ç: 15,7 cm Hamur: 2,5 YR 7/8 (açık kırmızı) Astar: 2,5 YR 5/8 (kırmızi) Benzerleri: Hayes 1985, 63 tav. XIV/3; Beyll 1993, 11, 26 taf. 3/35; Ladstatter 2000, abb. 5; Meriç 2002, 53 taf. 24/K 247; Hayes 2008, 38, 151 fig. 11/303; Ladstatter 2008, 103 taf. 276/TS29; Ladstatter 2010, 222 taf. 79/A-K 281; Uygun 2011, 67, 231-232 lev. 29/440. Tarih: MS 75-125.

Kat. No. 22 (Fig. 19.4)

Envanter No: 87-HY-11-03 Form No: Mtr Aşağı Hamam Palaestra Form 11 (DSB 2- Hayes Form 58) Form: Tabak Buluntu Yeri ve Seviyesi: S- 18 plan karesi, 42,67 m-41,65m Buluntu Tarihi: 30.06.2011 Ölçüler: Y: 2,6 cm; A.Ç: 12 cm Hamur: 2,5 YR 6/8 (açık kırmızı) Astar: 2,5 YR 5/8 (kırmızı) Benzerleri: Hayes 1985, 63 tav. XIV/3; Beyll 1993, 11, 26 taf. 3/35; Ladstatter 2000, abb. 5; Meriç 2002, 53 taf. 24/K 247; Hayes 2008, 38, 151 fig. 11/303; Ladstatter 2008, 103 taf. 276/TS29; Ladstatter 2010, 222 taf. 79/A-K 281; Uygun 2011, 67, 231-232 lev. 29/440. Tarih: MS 75125 .

Kat. No. 23 (Fig. 19.5)

Envanter No: 039-HY-03-25 Form No: Mtr Aşağ Hamam Palaestra Form 11 (DSB 2- Hayes Form 58) Form: Tabak Buluntu Yeri ve Seviyesi: Han Yıkığ MYD duvar yıkığı batı apsis, 44,89 m-43,63 m Buluntu Tarihi: 10.10.2003 Ölçüler: Y: 1,4 cm; K.Ç: 7,4 cm Hamur: 2,5 YR 6/8 (açık kırmızı) Astar: 2,5 YR 4/8 (kırmızı) Benzerleri: Hayes 1985, 63 tav. XIV/3; Beyll 1993, 11, 26 taf. 3/35; Ladstatter 2000, abb. 5; Meriç 2002, 53 taf.24/K 247; Hayes 2008, 38, 151 fig. 11/309; Ladstatter 2008, 103 taf. 276/TS38; Ladstatter 2010, 222 taf. 79/A-K 283; Uygun 2011, 67, 231-232 lev. 29/440. Tarih: MS 75-125.

Kat. No. 24 (Fig. 19.6)

Envanter No: 173-HY-05.56 Form No: Mtr Aşağı Hamam Palaestra Form 11 (DSB 2- Hayes Form 58) Form: Tabak Buluntu Yeri ve Seviyesi: I- 19 plan karesi, 46,02 m-44,70 m Buluntu Tarihi: 04.08.2005 
Ölçüler: Y: 2,6 cm; K.Ç: 9,4 cm Hamur: 2,5 YR 5/6 (kırmızı) Astar: 2,5 YR 4/8 (kırmızı) Benzerleri: Hayes 1985, 63 tav. XIV/3; Beyll 1993, 11, 26 taf. 3/35; Ladstatter 2000, abb. 5; Meriç 2002, 53 taf. 24/K 247; Erol 2004, 74, 263 lev. 121/çiz. 544; Hayes 2008, 38, 151 fig. 11/309; Ladstatter 2008, 103 taf. 276/TS38; Ladstatter 2010, 222 taf. 79/A-K 283; Uygun 2011, 67, 231-232 lev. 29/440; Aybek et al. 2021, 26-27, 76 pl. 17/cat.151. Tarih: MS 75-125.

\section{Kat. No. 25 (Fig. 19.7)}

Envanter No: 044-HY-03-25 Form No: Mtr Aşağ Hamam Palaestra Form 11 (DSB 2- Hayes Form 58) Form: Tabak Buluntu Yeri ve Seviyesi: MDY duvar yıkığı batı apsis, 44,89 m-43,63 m Buluntu Tarihi: 10.10.2003 Ölçüler: Y: 4,5 cm; A.Ç: 14,4 cm; K.Ç: 7 cm Hamur: 2,5 YR 6/8 (açık kırmızı) Astar: 2,5 YR 5/8 (kırmızı) Benzerleri: Hayes 1985, 63 tav. XIV/3; Güngör 2005, 48, 115 lev. 27/147; Ladstatter 2005, 324-325 taf. 184/K 590. Tarih: MS III. yüzyılın ilk yarisi.

\section{Kat. No. 26 (Fig. 19.8)}

Envanter No: 58-90-HY-12-77 Form No: Mtr Aşağ Hamam Palaestra Form 11 (DSB 2- Hayes Form 58) Form: Tabak Buluntu Yeri ve Seviyesi: P-24 plan karesi, 43,46 m - 42,52 m, Buluntu Tarih: 31.07.2012 Ölçüler: Y: 2,9 cm; A.Ç: 10,2 cm; K.Ç: 5 cm Hamur: 2,5 YR 6/8 (açık kırmızı) Astar: 10 R 5/8 (kırmızı) Benzerleri: Hayes 1985, 63 tav. XIV/3; Güngör 2005, 48, 115 lev. 27/147; Ladstatter 2005, 324-325 taf. 184/K 590. Tarih: MS III. yüzyılın ilk yarisi.

\section{Kat. No. 27 (Fig. 20.1)}

Envanter No: 78-HY-10-107 Form No: Mtr Aşağ1 Hamam Palaestra Form 12 (DSB 2- Hayes Form 60) Form: Tabak Buluntu Yeri ve Seviyesi: Palaestra hamam önü, K- 19, K-20 plan kareleri, 43,70 m - 43,20 m Buluntu Tarihi: 27.08.2010 Ölçüler: Y: $2,9 \mathrm{~cm}$; A.Ç: 15,4 cm; K.Ç: 12,4 cm Hamur: 5 YR 5/6 (sarımsı kırmızı) Astar: 2,5 YR 4/8 (kırmızı) Benzerleri: Robinson 1959, 25 pl. 61/G25; Hayes 1973, 452-454, pl. 87/152; Unterkircher 1983, 184 abb. 3/12.12; Hayes 1985, 64 tav. XIV/6; Williams 1989, 19-20 fig. 7/Nos 104; Zelle 1997, 50-51 abb. 9/86; Ladstatter 2000, 100 abb.6/2; Vapur 2001, 20-23, 25-26 çiz. 2/9; Meriç 2002, 53-54, 62 taf. 25/K 260; Wintermeyer 2004, 145-146 abb. 1426 Typ Sch 4a.2; Güngör 2005, 47,
114 lev. 25/138; Hayes 2008, 39, 155 fig. 12/346; Uygun 2011, 68-69, 233 lev. 30/452; Vapur 2013, 644, 652 çiz. 1/12; Ekin-Meriç \& Öz 2017, 266, 275 çiz. 154; Ladstatter \& Liedl 2020, 40 taf. 3/K 29; Aybek et al.2021, 26-27, 76 pl. 17/cat.152, 29, 82 pl.21/cat.198. Tarih: MS I. yüzyılın ikinci yarısı.

Kat. No. 28 (Fig. 20.2)

Envanter No: 47-HY-05-171 Form No: Mtr Aşağı Hamam Palaestra Form 12 (DSB 2- Hayes Form 60) Form: Tabak Buluntu Yeri ve Seviyesi: J - 18, K- 18 plan kareleri, 44,20 m-43,88 m Buluntu Tarihi: 06.09.2005 Ölçüler: Y: 3 cm; A.Ç: 15,7 cm; K.Ç: 11,4 cm Hamur: 2,5 YR 6/8 (açık kırmızı) Astar:10 R 5/8 (kırmızı) Benzerleri: Robinson 1959, 25 pl. 61/G25; Hayes 1973, 452-454 pl. 87/152; Unterkircher 1983, 184 abb. 3/12.12; Hayes 1985, 64 tav. XIV/6; Williams 1989, 19-20 fig. 7/Nos 104; Zelle 1997, 50-51 abb. 9/86; Ladstatter 2000, 100 abb. 6/2; Vapur 2001, 20-23, 25-26 çiz. 2/9; Meriç 2002, 53-54, 62 taf. 25/K 260; Wintermeyer 2004, 145-146 abb. 1426 Typ Sch 4a.2; Güngör 2005, 47, 114 lev. 25/138; Hayes 2008, 39, 155 fig. 12/346; Uygun 2011, 68-69, 233 lev. 30/452; Vapur 2013, 644, 652 çiz. 1/12; Ekin-Meriç \& Öz 2017, 266, 275 çiz. / 54; Ladstatter \& Liedl 2020, 40 taf. 3/K 29; Aybek et al. 2021, 26-27, 76 pl. 17/cat.152, 29, 82 pl. 21/cat.198. Tarih: MS I. yüzyılın ikinci yaris1.

\section{Kat. No. 29 (Fig. 20.3)}

Envanter No: 42-HY-15-11 Form No: Mtr Aşağ Hamam Palaestra Form 12 (DSB 2- Hayes Form 60) Form: Tabak Buluntu Yeri ve Seviyesi: 38 (G-7, H7) plan kareleri, Kuzey mozaikli salon doğusu hamam kuzey duvarı yanı, 42,97 m-42,67 m Buluntu Tarihi: 13.07.2015 Ölçüler: Y: 1,9 cm; A.Ç: $11,6 \mathrm{~cm}$ Hamur: 2,5 YR 5/6 (kırmızı) Astar: 2,5 YR 5/8 (kırmizı) Benzerleri: Robinson 1959, 25 pl. 61/G25; Hayes 1973, 452-454 pl. 87/152; Unterkircher 1983, 184 abb. 3/12.12; Hayes 1985, 64 tav. XIV/6; Williams 1989, 19-20 fig. 7/Nos 104; Zelle 1997, 50-51 abb. 9/86; Ladstatter 2000, 100 abb. 6/2; Vapur 2001, 2023, 25-26 çiz. 2/9; Meriç 2002, 53-54, 62 taf.25/K 260; Wintermeyer 2004, 145-146 abb. 1426 Typ Sch 4a.2; Güngör 2005, 47, 114 lev. 25/138; Hayes 2008, 39, 155 fig. 12/346; Uygun 2011, 68-69, 233 lev. 30/452; Vapur 2013, 644, 652 çiz. 1/12; Ekin-Meriç \& Öz 2017, 266, 275 çiz. /54; Ladstatter \& Liedl 2020, 40 taf. 3/K 29. Tarih: MS I. yüzyılın ikinci yarısı. 
Kat. No. 30 (Fig. 20.4)

Envanter No: 44-HY-15-37 Form No: Mtr Aşağı Hamam Palaestra Form 12 (DSB 2- Hayes Form 60) Form: Tabak Buluntu Yeri ve Seviyesi: 49 E/F 6 plan kareleri, batı servis koridoru içi, 48,10 m-46,20 m Buluntu Tarihi:10.09.2015 Ölçüler: Y: 2,1 cm; A.Ç: 14,6 cm Hamur: 2,5 YR 5/6 (kırmızı) Astar: 2,5 YR 5/8 (kırmızi) Benzerleri: Robinson 1959, 25 pl. 61/G25; Hayes 1973, 452-454 pl. 87/152; Unterkircher 1983, 184 abb. 3/12.12; Hayes 1985, 64 tav. XIV/6; Williams 1989, 19-20 fig. 7/Nos 104; Zelle 1997, 50-51 abb. 9/86; Ladstatter 2000, 100 abb. 6/2; Vapur 2001, 20-23, 25-26 çiz. 2/9; Meriç 2002, 53-54, 62 taf. 25/K 260; Wintermeyer 2004, 145-146 abb. 1426 Typ Sch 4a.2; Güngör 2005, 47, 114 lev. 25/138; Hayes 2008, 39, 155 fig. 12/346; Uygun 2011, 68-69, 233 lev. 30/452; Vapur 2013, 644, 652 çiz. 1/12; EkinMeriç \& Öz 2017, 266, 275 çiz. /54; Ladstatter \& Liedl 2020, 40 taf.3/K 29. Tarih: MS I. yüzyılın ikinci yarısı.

Kat. No. 31 (Fig. 20.5)

Envanter No: 3-HY-12-69 Form No: Mtr Aşağ 1 Hamam Palaestra Form 12 (DSB 1- Hayes Form 60) Form: Tabak Buluntu Yeri ve Seviyesi: K-25, K-26 plan karesi, 43,46 m-43,27 m Buluntu Tarihi: 27.07.2012 Ölçüler: Y: 6 cm; A.Ç: 25,4 cm; K.Ç: 19,4 cm Hamur: 10 R 6/6 (açık kırmızı) Astar: 10 R 4/8 (kırmızı) Benzerleri: Hayes 1985, 64 tav. XIV/7; Kenrick 1985, 249-250 fig. 45/352.4; Ladstatter 2000, 100 abb. 6/13; Meriç 2002, 62 taf. 25/K 264; Ladstatter 2005, 310,312 taf. 176/K 439-K440 taf. 177/459; Hayes 2008, 39, 156 fig. 12/358; Ladstatter 2008, 104 taf. 277/TS42, TS44; Ekin-Meriç 2014, 20 pl. 1/3; Ekin-Meriç \& Öz 2017, 266, 275 çiz. /53. Tarih: MS II. yüzyılın ilk yarısı.

Kat. No. 32 (Fig. 20.6)

Envanter No: 104-HY-12-26 Form No: Mtr Aşağı Hamam Palaestra Form 12 (DSB 2- Hayes Form 60) Form: Tabak Buluntu Yeri ve Seviyesi: Palaestra O25 plan karesi, 43,54 m-42,89 m Buluntu Tarihi: 23.07.2012 Ölçüler: Y: $5,5 \mathrm{~cm}$; A.Ç: $23,2 \mathrm{~cm}$; K.Ç: 16,6 cm Hamur: 5 YR 6/8 (kırmızımsı sarı) Astar: 2,5 YR 5/8 (kırmızı) Benzerleri: Sackett 1992, 223-224 pl. 169/2; Gassner 1997, 132 taf. 43/509; Hayes 2008, 39, 155 fig. 12/354; Uygun 2011, 68-69, 234 lev. 31/458; Ekin-Meriç \& Öz 2017, 266, 275 çiz. /53; Aybek \& Gülbay 2019, 250 fig. 14; Aybek et al. 2021, 2324, 70 pl. 13/cat.108. Tarih: MS II. yüzyılın ilk yarısı.
Kat. No. 33 (Fig. 21.1)

Envanter No: 70-HY-10-100 Form No: Mtr Aşağ1 Hamam Palaestra Form 13 (DSB 2- Hayes Form 70) Form: Kase Buluntu Yeri ve Seviyesi: Palaestra hamam önü kuzeyi, K-19 plan karesi, 44,05 m-43,43 m Buluntu Tarihi: 24.08 .2010 Ölçüler: Y: $3,7 \mathrm{~cm}$; A.Ç: 11,2 cm Hamur: 2.5 YR 5/8 (kırmızı) Astar: 2,5 YR 4/8 (kırmızı) Benzerleri: Hayes 1985, 66-67 tav. XV/1; Gassner 1997, 133 taf. 43/515; Ladstatter 2000, 98-99 abb. 5; Meriç 2002, 63 taf. 26/K275; Güngör 2005, 110 lev. 22/113; Ladstatter 2005, 326 taf. 185/K 609; Hayes 2008, 157-158 fig. 13/381; Ladstatter 2008, 105 taf. 278/ TS58- TS59; Ladstatter 2010, 225 taf. 81/A-K 310; Uygun 2011, 70-71, 235 lev. 31/468; Vapur 2013, 654 çiz. 2/22.Tarih: MS I. yüzyıl sonu ile MS II. yüzyıl başı.

\section{Kat. No. 34 (Fig. 21.2)}

Envanter No: 32-HY-15-24 Form No: Mtr Aşağ Hamam Palaestra Form 13 (DSB 2- Hayes Form 70) Form: Kase Buluntu Yeri ve Seviyesi: 49 H-6 plan karesi, batı servis koridoru bitişik duvar önü, 49,35 m-47,79 m Buluntu Tarihi: 20.08.2015 Ölçüler: Y: 4,1 cm; A.Ç: 9 cm Hamur: 10 R 5/8 (kırmızi) Astar: 2,5 YR 5/8 (kırmızi) Benzerleri: Hayes 1985, 66-67 tav. XV/1; Gassner 1997, 133 taf. 43/515; Ladstatter 2000, 98-99 abb. 5; Meriç 2002, 63 taf. 26/K275; Güngör 2005, 110 lev. 22/113; Ladstatter 2005, 326 taf. 185/K 609; Hayes 2008, 157-158 fig. 13/381; Ladstatter 2008, 105 taf. 278/ TS58- TS59; Ladstatter 2010, 225 taf. 81/A-K 310; Uygun 2011, 70-71, 235 lev. 31/468; Vapur 2013, 654 çiz. 2/22; Aybek \& Gülbay 2019, 250 fig. 14; Aybek et al. 2021, 23-24, 70 pl. 13/cat.109. Tarih: MS I. yüzyıl sonu ile MS II. yüzyıl başı.

Kat. No. 35 (Fig. 21.3)

Envanter No: 8-HY-14-70 Form No: Mtr Așağı Hamam Palaestra Form 13 (DSB 2- Hayes Form 70) Form: Kase Buluntu Yeri ve Seviyesi: 37 (I-9, H-9, G-9) plan karesi 2x15 m'lik düzenleme çalışması, 48,74 m-47,70 m Buluntu Tarihi: 20.10.2014 Ölçüler: Y: 3,5 cm; A.Ç: $11 \mathrm{~cm}$ Hamur: 2,5 YR 6/6 (açık kırmızi) Astar: 2,5 YR 5/8 (kırmızı) Benzerleri: Hayes 1985, 66-67 tav. XV/1; Gassner 1997, 133 taf. 43/515; Ladstatter 2000, 98-99 abb. 5; Meriç 2002, 63 taf. 26/K278; Güngör 2005, 110 lev. 22/116; Ladstatter 2005, 326 taf. 185/K 608-K609; Ladstatter 2008, 105 taf. 278/ TS58-TS59; Ladstatter 2010, 225 taf. 
81/A-K 311; Uygun 2011, 70-71, 235 lev. 31/468; Vapur 2013, 654 çiz. 2/22; Aybek \& Gülbay 2019, 250 fig. 14; Ladstatter \& Liedl 2020, 41 taf. 4/K 48. Tarih: MS I. yüzyıl sonu ile MS II. yüzyıl başı.

Kat. No. 36 (Fig. 21.4)

Envanter No: 16-HY-14-70 Form No: Mtr Aşağ Hamam Palaestra Form 13 (DSB 2- Hayes Form 70) Form: Kase Buluntu Yeri ve Seviyesi: 37 (I-9, H-9, G-9) plan karesi 2x15 m'lik düzenleme çalışması, 48,74 m-47,70 m Buluntu Tarihi: 20.10.2014 Ölçüler: Y: 2,7 cm; A.Ç: 14,8 cm Hamur: 2,5 YR 6/6 (açık kırmızi) Astar: 2,5 YR 5/8 (kırmızı) Benzerleri: Hayes 1985, 66-67 tav. XV/1; Gassner 1997, 133 taf. 43/515; Ladstatter 2000, 98-99 abb. 5; Meriç 2002, 63 taf. 26/K275; Güngör 2005, 110 lev. 22/113; Ladstatter 2005, 326 taf. 185/K 609; Hayes 2008, 157-158 fig. 13/381; Ladstatter 2008, 105 taf. 278/TS58- TS59; Ladstatter 2010, 225 taf. 81/A-K 310; Uygun 2011, 70-71, 235 lev. 31/468; Vapur 2013, 654 çiz. 2/22; Aybek \& Gülbay 2019, 250 fig. 14; Aybek et al. 2021, 29, $82 \mathrm{pl}$. 21/cat.199. Tarih: MS I. yüzyll sonu ile MS II. yüzyıl başı.

Kat. No. 37 (Fig. 21.5)

Envanter No: 12-HY-14-75 Form No: Mtr Aşağ Hamam Palaestra Form 13 (DSB 2- Hayes Form 70) Form: Kase Buluntu Yeri ve Seviyesi: 37 (I-9, H-9) plan kareleri 2x10 metrelik düzenleme çalışması, 48,92 m-48,09 m Buluntu Tarihi: 24.10.2014 Ölçüler: Y: 2,1 cm; K.Ç: 5,5 cm Hamur: 2,5 YR 5/6 (kırmızı) Astar: 10 R 4/8 (kırmızı) Benzerleri: Hayes 1985, 66-67 tav. XV/1; Ladstatter 2000, 98-99 abb. 5; Güngör 2005, 110 lev. 22/118; Hayes 2008, 159 fig. 13/398; Ladstatter 2008, 106 taf. 278/TS67; Ladstatter 2010, 262 taf. 105/A-K 761-762; Şimşek et al. 2011, 116 lev. 103/360; Uygun 2011, 70-71, 235 lev. 31/466; Vapur 2013, 655-656 çiz. 2/29; Ladstatter \& Liedl 2020, 41 taf. 4/K 50. Tarih: MS I. yüzyıl sonu ile MS II. yüzyıl başı.

Kat. No. 38 (Fig. 21.6)

Envanter No: 13-HY-14-20 Form No: Mtr Aşağı Hamam Palaestra Form 13 (DSB 2- Hayes Form 70) Form: Kase Buluntu Yeri ve Seviyesi: Buluntu Yeri ve Seviyesi: 37 (I-9, H-9, G-9) plan karesi 2x15 m'lik düzenleme çalışması, 48,74 m-47,70 m Buluntu Tarihi: 20.10.2014 Ölçüler: Y: $1 \mathrm{~cm}$; K.Ç: $4,5 \mathrm{~cm}$ Hamur: 2,5 YR 6/8 (açık kırmızı) Astar: 2,5 YR 4/8 (kır- mızı) Benzerleri: Hayes 1985, 66-67 tav. XV/1; Ladstatter 2000, 98-99 abb. 5; Güngör 2005, 110 lev. 22/118; Hayes 2008, 159 fig. 13/398; Ladstatter 2008, 106 taf. 278/TS67; Ladstatter 2010, 262 taf. 105/A-K 761-762; Şimşek et al. 2011, 116 lev. 103/360; Uygun 2011, 70-71, 235 lev. 31/466; Vapur 2013, 655-656 çiz. 2/29; Ladstatter \& Liedl 2020, 41 taf. 4/K 50. Tarih: MS I. yüzyıl sonu ile MS II. yüzyıl başı.

Kat. No. 39 (Fig. 21.7)

Envanter No: 6-HY-14-20 Form No: Mtr Așağı Hamam Palaestra Form 13 (DSB 2- Hayes Form 70) Form: Kase Buluntu Yeri ve Seviyesi: 37 (I-9, H-9, G-9) plan karesi 2x15 m'lik düzenleme çalışması, 48,74 m-47,70 m Buluntu Tarihi: 20.10.2014 Ölçüler: Y: 5,1 cm; A.Ç: 10,6 cm; K.Ç: 4,6 cm Hamur: 2,5 YR 5/8 (kırmızı) Astar: 2,5 YR 4/8 (kırmızı) Benzerleri: Hayes 1985, 66-67 tav. XV/1; Ladstatter 2000, 98-99 abb. 5; Güngör 2005, 110 lev. 22/117; Ladstatter 2008, 106 taf. 278/TS67; Ladstatter 2010, 262 taf. 105/A-K 761; Uygun 2011, 70-71, 235 lev. 31/466, 468; Vapur 2013, 655-656 çiz. 2/26, 29. Tarih: MS III. yüzyıl.

\section{Kat. No. 40 (Fig. 21.8)}

Envanter No: 94-HY-12-42 Form No: Mtr Aşağ1 Hamam Palaestra Form 13 (DSB 2- Hayes Form 70) Form: Kase Buluntu Yeri ve Seviyesi: Palaestra K 25-26 plan kareleri, ikinci havuz içi kanal, 44,10 m43,46 m Buluntu Tarihi: 25.07.2012 Ölçüler: Y: 5,2 cm; A.Ç: 10 cm; K.Ç: 5,4 cm Hamur: 2,5 YR 6/8 (açık kırmızı) Astar: 2,5 YR 5/8 (kırmızı) Benzerleri: Ladstatter 2005, 353-354 taf. 204/K 873; Ekin-Meriç 2014, 18, 21, Cat.7-10 pl. 2/7-10. Tarih: MS III. yüzy1l.

\section{Kat. No. 41 (Fig. 21.9)}

Envanter No: HY-12-42-7 (10738) Form No: Mtr Aşağı Hamam Palaestra Form 13 (DSB 2- Hayes Form 70) Form: Kase Buluntu Yeri ve Seviyesi: Palaestra K 25-26 plan kareleri, ikinci havuz içi kanal, 44,10 m-43,46 m Buluntu Tarihi: 25.07.2012 Ölçüler: Y: 4,3 cm; A.Ç: $10 \mathrm{~cm}$; K.Ç: 5,4 cm Hamur: 2,5 YR 7/4 (açık kırmızımsı kahverengi) Astar: 10 R 5/6 (kırmızı) Benzerleri: Ladstatter 2005, 353-354 taf. 204/K 873; Ekin-Meriç 2014, 18, 21, Cat.7-10 pl. 2/710. Tarih: MS III. yüzyıl. 
Kat. No. 42 (Fig. 21.10)

Envanter No: HY-12-42-19 (10750) Form No: Mtr Aşağı Hamam Palaestra Form 13 (DSB 2- Hayes Form 70) Form: Kase Buluntu Yeri ve Seviyesi: Palaestra K 25-26 plan kareleri, ikinci havuz içi kanal, 44,10 m-43,46 m Buluntu Tarihi: 25.07.2012 Ölçüler: Y: 5,2 cm; A.Ç: $10 \mathrm{~cm}$; K.Ç: 4,9 cm Hamur: 2,5 YR 7/4 (açık kırmızımsı kahverengi) Astar: 10 R 5/8 (kırmızi) Benzerleri: Ladstatter 2005, 353-354 taf. 204/K 873; Ekin-Meriç 2014, 18, 21, Cat.7-10 pl. 2/710. Tarih: MS III. yüzyıl.

Kat. No. 43 (Fig. 21.11)

Envanter No: HY-12-69-2 (10765) Form No: Mtr Aşağı Hamam Palaestra Form 13 (DSB 2- Hayes Form 70) Form: Kase Buluntu Yeri ve Seviyesi: Palaestra K-25, K-26 plan karesi ikinci havuz içi kanal 43,46 m-43,27 m Buluntu Tarihi: 27.07.2012 Ölçüler: Y: 5,2 cm; A.Ç: $10 \mathrm{~cm}$; K.Ç: 4,9 cm Hamur: 2,5 YR 7/4 (açık kırmızımsı kahverengi) Astar: 10 R 5/8 (kırmızı) Benzerleri: Ladstatter 2005, 353-354 taf. 204/K 873; Ekin-Meriç 2014, 18, 21, Cat.7-10 pl. 2/710. Tarih: MS III. yüzyıl.

Kat. No. 44 (Fig. 21.12)

Envanter No: HY-12-69-3 (10766) Form No: Mtr Aşağı Hamam Palaestra Form 13 (DSB 2- Hayes Form 70) Form: Kase Buluntu Yeri ve Seviyesi: Palaestra K-25, K-26 plan karesi ikinci havuz içi kanal 43,46 m-43,27 m Buluntu Tarihi: 27.07.2012 Ölçüler: Y: $3,7 \mathrm{~cm}$; A.Ç: $8 \mathrm{~cm}$; K.Ç: 3,8 cm Hamur: 2,5 YR 6/6 (açık kırmızı) Astar: 10 R 5/8 (kırmızı) Benzerleri: Ladstatter 2005, 353-354 taf. 204/K 873; EkinMeriç 2014, 18,21, Cat.7-10 pl. 2/7-10. Tarih: MS III. yüzyıl.

\section{Kat. No. 45 (Fig.22)}

Envanter No: 73-HY-10-113 Form No: Mtr Aşağı Hamam Palaestra Form 14 (DSB 2- Hayes Form 74 a) Form: Kase Buluntu Yeri ve Seviyesi: Palaestra hamam önü kuzeyi, L-19 plan karesi, 44,29 m-42,51 m Buluntu Tarihi: 31.08.2010 Ölçüler: Y: 2,5 cm; A.Ç: 14 cm Hamur: 2,5 YR 6/8 (açık kırmızı) Astar: 2,5 YR 4/8 (kırmızı) Benzerleri: Hayes 1985, 68 tav. XV/6; Hayes 2008, 39, 154 fig. 12/341-342; Uygun 2011, 71-72, 236-237 lev. 32/477, 479. Tarih: MS I. yüzyıl sonu ile MS II. yüzyıl başı
Kat. No. 46 (Fig. 23)

Envanter No: 791-HY-05-210 Form No: Mtr Aşağı Hamam Palaestra Form 15 (DSB 2- Hayes Form 76 a) Form: Kase Buluntu Yeri ve Seviyesi: F 18 (Apsis içi), 45,50 m-45,10 m Buluntu Tarihi: 16.09.2005 Ölçüler: Y: 6,3 cm; A.Ç: 14,5 cm Hamur: 2,5 YR 5/6 (kırmızı) Astar: 2,5 YR 4/8 (kırmızı) Benzerleri: Hayes 1973, 454 pl. 87/154; Unterkircher 1983, 187-188 abb. 5/21.5; Hayes 1985, 68-69 tav. XV/10; Kenrick 1985, 254 fig. 46/361.3; Beyll 1993, 24 taf. 2/19; Meriç 2002, 63 taf. 26/K 285; Hayes 2008, 40, 160 fig. 13/421. Tarih: MS I. yüzyılın ikinci yarısı.

Kat. No. 47 (Fig. 24)

Envanter No: 102-HY-12-20 Form No: Mtr Aşağı Hamam Palaestra Form 16 (DSB 2- Hayes Form 78) Form: Kase Buluntu Yeri ve Seviyesi: Palaestra P-23 plan karesi, mozaik üstü, 43,45 m-42,24 m Buluntu Tarihi: 18.07.2012 Ölçüler: Y: 3,1 cm; A.Ç:14 K.Ç: 8,2 cm Hamur: 2,5 YR 6/8 (açık kırmızı) Astar: 2,5 YR 4/8 (kırmızı) Benzerleri: Robinson 1959, 27 pl. 65/G50; Hellström 1965, 70 pl. 36/248; Hayes 1985, 69 tav. XV/13; Hayes 2008, 40, 160 fig. 13/419-420; Vapur 2011, 154 çiz.3/30-31. Tarih: MS II. yüzyılın ilk yarısı.

Kat. No. 48 (Fig. 25.1)

Envanter No: 33-HY-15-35 Form No: Mtr Aşağ1 Hamam Palaestra Form 17 (DSB 2- Hayes Form 80) Form: Kase Buluntu Yeri ve Seviyesi: 49 G-6, H-6 plan karesi, batı servis koridoru girişi, 48,63 m-47,81 m Buluntu Tarihi: 07.09.2015 Ölçüler: Y: 3,9 cm; A.Ç: 12,6 cm; K.Ç: 3,5 cm Hamur: 2,5 YR 6/6 (açık kırmızı) Astar: 2,5 YR 4/8 (kırmızı) Benzerleri: Waage 1948, 40 pl. VII/667; Robinson 1959, 87 pl. 61/M31; Hayes 1985, 69-70 tav. XV/15; Kenrick 1985, 255 fig.46/B 362; Slane 1990, 51 fig. 6/100; Hayes 1991, 53 fig. XXI/14; Sackett 1992, 212 pl. 156/8; Beyll 1993, 24 taf. 2/22-25; Gassner 1997, 133 taf. 43/511; Erol 2004, 165-166 lev. 49/235; Ladstatter 2005, 318-319 taf. 181/K526; Hayes 2008, 38, 152153 fig. 12/316-317,320; Ladstatter 2008, 107 taf. 279/ TS80, TS83; Uygun 2011, 72, 237 lev. 32/480; Vapur 2011, 150 çiz. 2/15; Vapur 2013, 657 çiz. 2/35; Eliüşük 2021, 23-24, 29-30 lev. 5/25, lev. 6/26. Tarih: MS I. yüzyıl sonu ile MS II. yüzyılın ilk yarısı. 
Kat. No. 49 (Fig. 25.2)

Envanter No: 29-HY-15-21 Form No: Mtr Aşağı Hamam Palaestra Form 17 (DSB 2- Hayes Form 80) Form: Kase Buluntu Yeri ve Seviyesi: 49 H-6 plan karesi, batı servis koridoru giriși, 48,92 m-47,93 m Buluntu Tarihi: 17.08.2015 Ölçüler: Y: 4,2 cm; A.Ç: 18,2 cm Hamur: 2,5 YR 6/6 (açık kırmızı) Astar: 2,5 YR 5/8 (kırmızı) Benzerleri: Waage 1948, 40 pl. VII/667; Robinson 1959, 87 pl. 61/M31; Hayes 1985, 69-70 tav. XV/15; Kenrick 1985, 255 fig. 46/B 362; Slane 1990, 51 fig. 6/100; Hayes 1991, 53 fig. XXI/14; Sackett 1992, 212 pl. 156/8; Beyll 1993, 24 taf. 2/2225; Gassner 1997, 133 taf. 43/511; Erol 2004, 165- 166 lev. 49/235; Ladstatter 2005, 318-319 taf. 181/K526; Hayes 2008, 38, 152-153 fig. 12/316-317,320; Ladstatter 2008, 107 taf. 279/TS80, TS83; Uygun 2011, 72, 237 lev. 32/480; Vapur 2011, 150 çiz. 2/15; Vapur 2013, 657 çiz. 2/35; Eliüşük 2021, 23-24, 29-30 lev. 5/25, lev. 6/26. Tarih: MS I. yüzyll sonu ile MS II. yüzyılın ilk yarısı.
Kat. No. 50 ( Fig. 25.3)

Envanter No: 21-HY-14-75 Form No: Mtr Aşağı Hamam Palaestra Form 17 (DSB 2- Hayes Form 80) Form: Kase Buluntu Yeri ve Seviyesi: 37 (I-9, H-9) plan kareleri 2x10 metrelik alan, 48,92 m-48,09 m. Buluntu Tarihi: 24.10 .2014 Ölçüler: Y: 3 cm; K.Ç: 11,2 cm Hamur: 2,5 YR 4/6 (kırmızı) Astar: 2,5 YR 4/8 (kırmızi) Benzerleri: Waage 1948, 40 pl. VII/667; Robinson 1959, 87 pl. 61/M31; Hayes 1985, 69-70 tav. XV/15; Kenrick 1985, 255 fig. 46/B 362; Slane 1990, 51 fig. 6/100; Hayes 1991, 53 fig. XXI/14; Sackett 1992, 212 pl. 156/8; Beyll 1993, 24 taf. 2/22-25; Gassner 1997, 133 taf. 43/511; Erol 2004, 165-166 lev. 49/235; Ladstatter 2005, 318-319 taf. 181/K526; Hayes 2008, 38, 152-153 fig. 12/316-317,320; Ladstatter 2008, 107 taf. 279/TS80, TS83; Uygun 2011, 72, 237 lev. 32/480; Vapur 2011, 150 çiz. 2/15; Vapur 2013, 657 çiz. 2/35; Eliüşük 2021, 23-24, 29-30 lev. 5/25, lev. 6/26. Tarih: MS I. yüzyıl sonu ile MS II. yüzyılın ilk yarıs. 

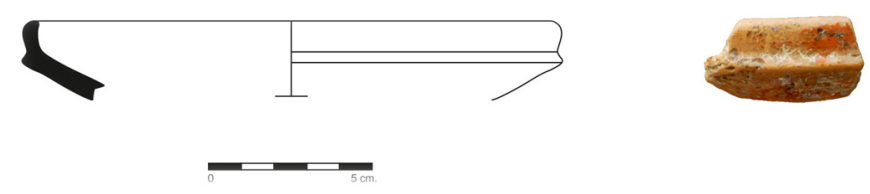

Fig. 9 Kat. No. 1
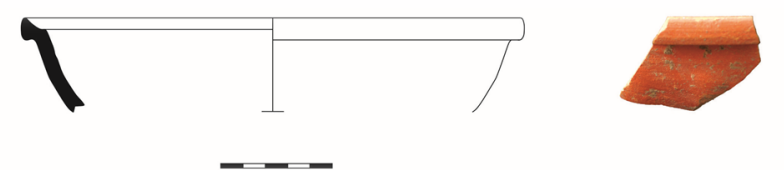

Fig. 10.1 Kat. No. 2

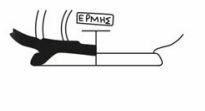

-

Fig. 10.2 Kat. No. 3

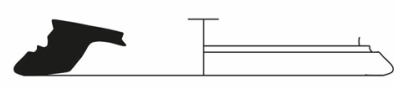

$5-5 \mathrm{~m}$

Fig. 11 Kat. No. 5

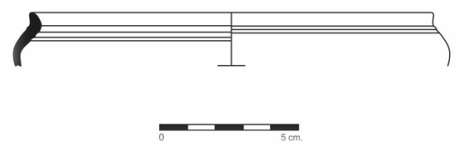

Fig. 13.1 Kat. No. 7
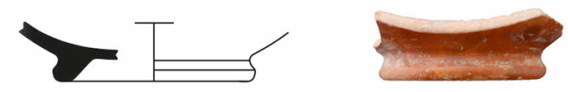

Fig. 14.1 Kat. No. 9
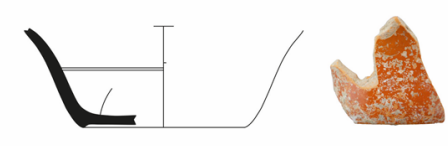

Fig. 15 Kat. No. 11

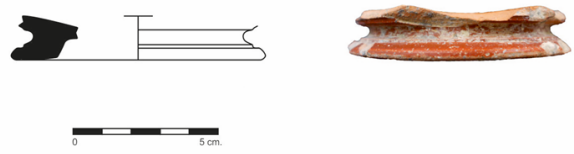

Fig. 10.3 Kat. No. 4
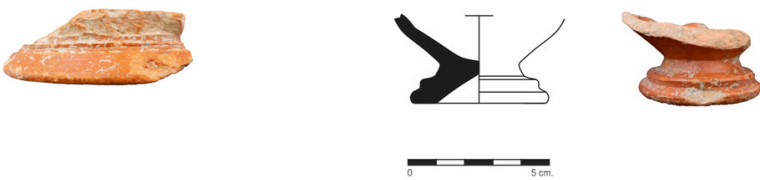

Fig. 12 Kat. No. 6
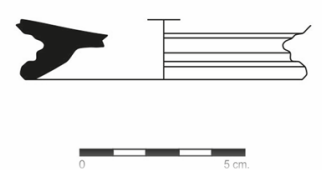

Fig. 13.2 Kat. No. 8

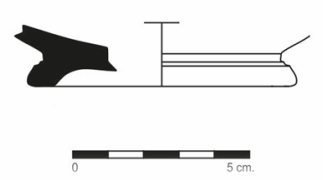

Fig. 14.2 Kat. No. 10

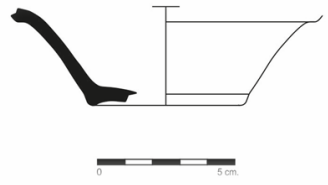

Fig. 16 Kat. No. 12 


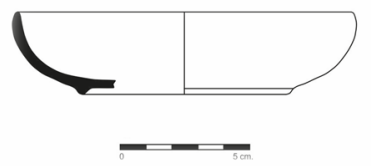

Fig. 17.1 Kat. No. 13

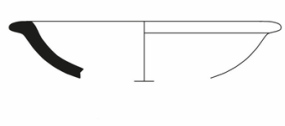

Fig. 18.1 Kat. No. 15

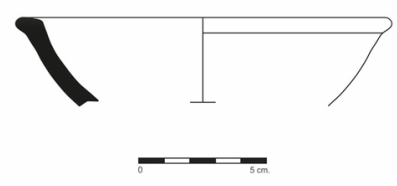

Fig. 18.3 Kat. No. 17

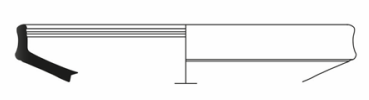

Fig. 19.1 Kat.No. 19

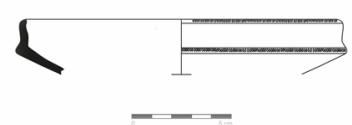

Fig. 19.3 Kat. No. 21

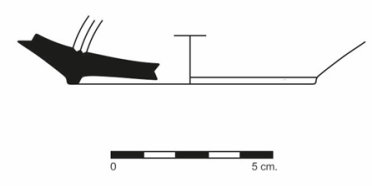

Fig. 19.5 Kat. No. 23
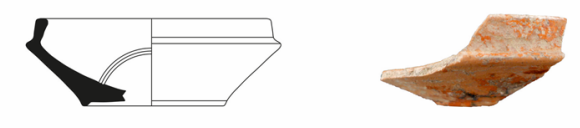

Fig.19.7 Kat. No. 25

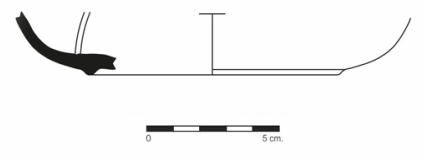

Fig. 17.2 Kat. No. 14

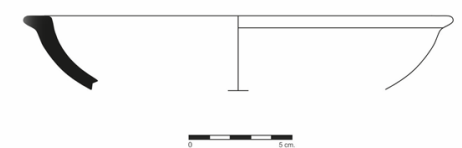

Fig. 18.2 Kat. No. 16
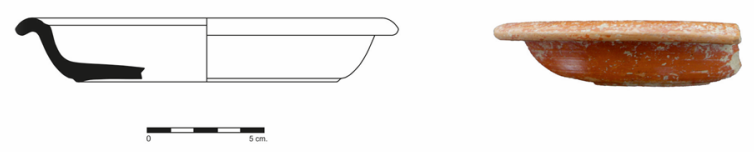

Fig. 18.4 Kat. No. 18

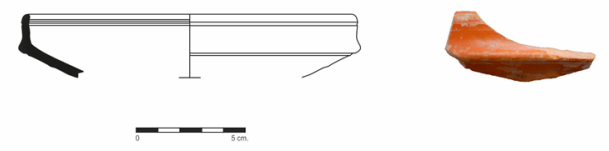

Fig. 19.2 Kat.No. 20
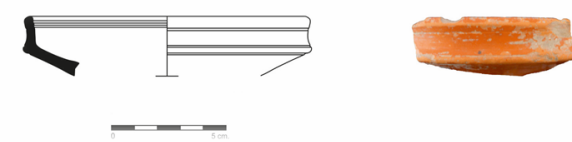

Fig. 19.4 Kat. No. 22

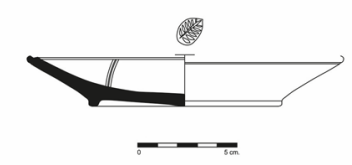

Fig. 19.6 Kat. No. 24
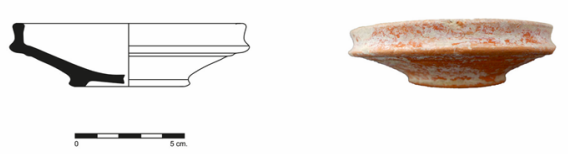

Fig. 19.8 Kat.No. 26 


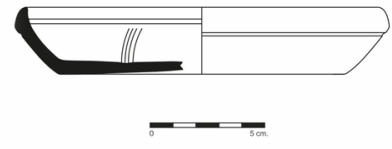

Fig. 20.1 Kat. No. 27

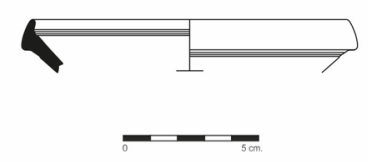

Fig. 20.3 Kat. No. 29

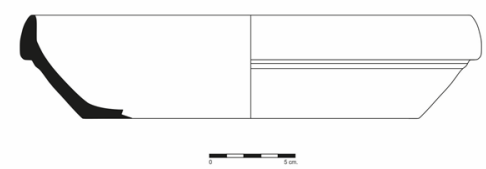

Fig. 20.5 Kat. No. 31
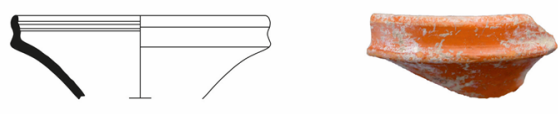

Fig. 21.1 Kat. No. 33

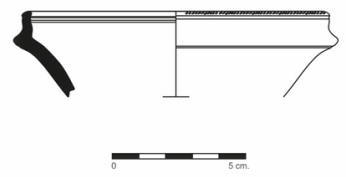

Fig. 21.3 Kat. No. 35
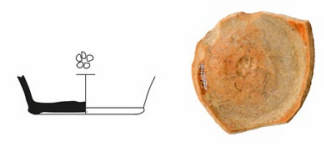

Fig. 21.5 Kat. No. 37
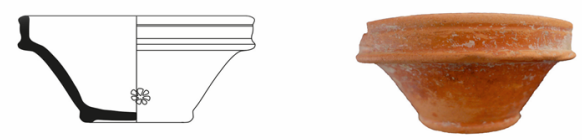

Fig. 21.7 Kat. No. 39

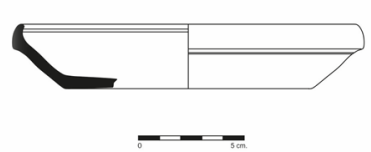

Fig. 20.2 Kat. No. 28

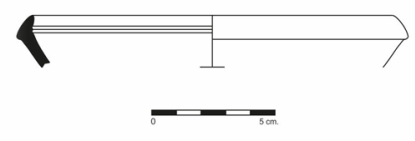

Fig. 20.4 Kat. No. 30

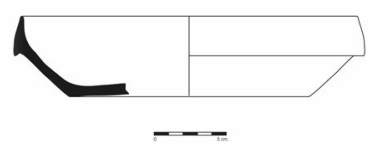

Fig. 20.6 Kat. No.32
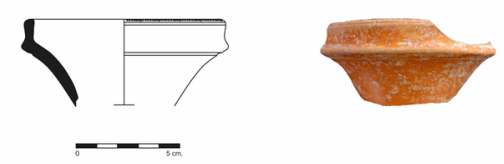

Fig. 21.2 Kat. No. 34
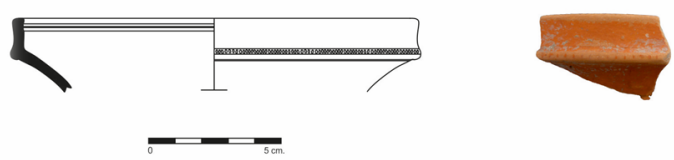

Fig. 21.4 Kat. No. 36
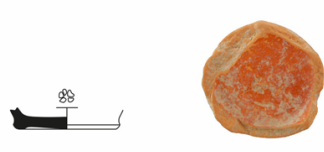

Fig.2 1.6 Kat. No. 38
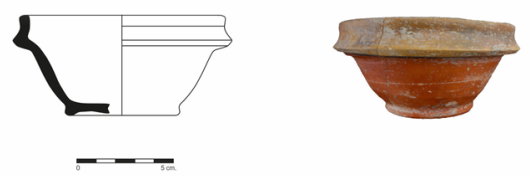

Fig. 21.8. Kat. No. 40 


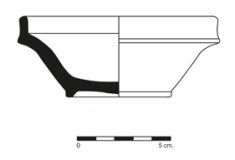

Fig. 21.9 Kat. No. 41
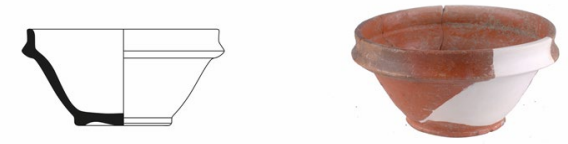

Fig. 21.11 Kat. No. 43

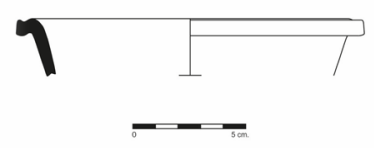

Fig. 22 Kat. No. 45

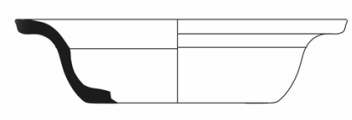

Fig. 24 Kat. No. 47
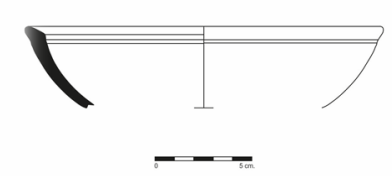

Fig. 25.2 Kat. No. 49
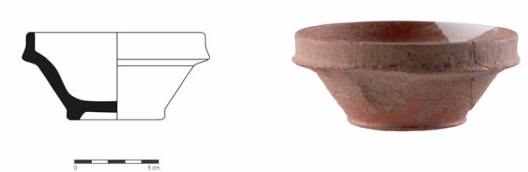

Fig.21.10 Kat.No. 42
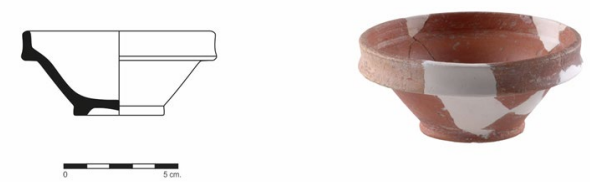

Fig. 21.12 Kat. No. 44
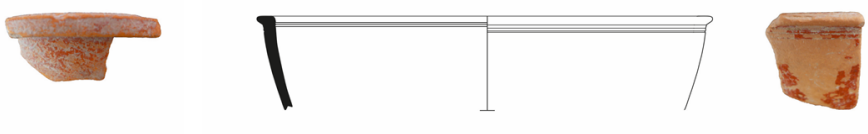

Fig. 23 Kat. No. 46
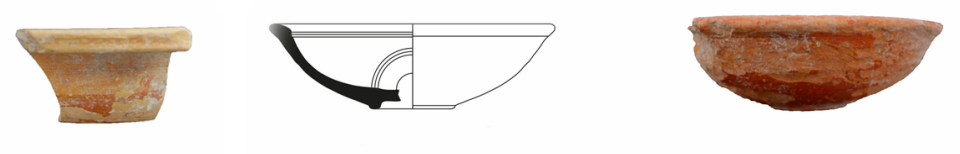

Fig. 25.1 Kat. No. 48
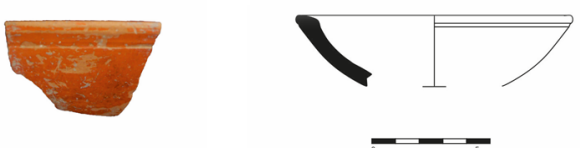

Fig. 25.3 Kat. No. 50 


\section{BİBLIYOGRAFYA}

Anderson-Stojanovic V. R. 1992, Stobi: The Hellenistic and Roman Pottery. Princeton, New Jersey.

Ateş G. 2001, "Eastern Sigillata B in Aizanoi". AA, 319-332.

Ateş G. 2015, Die rote Feinkeramik von Aizanoi als lokaler Kulturtrager, Untersuchungen zum Verhaltnis von lokaler roter Feinkeramik und importierter Sigillata, Archaologische Forschungen Band 32, Aizanoi Band 2. Berlin.

Aybek S., A. K. Öz \& A. Ekin-Meriç 2011, "Metropolis 2010 Yılı Kazı Çalışmaları”. KST XXXIII/2, 313-337.

Aybek S., A. K. Öz, A. Ekin-Meriç, Y. Balım \& B. Arslan 2014, “Metroplis Kazısı’nda 2013 Yılı Çalışmaları”. KST XXXVI/2, 325-347.

Aybek S. 2014, "Ausgrabungen am unteren (Han Yıkığı) römischen Bad und an der Palastra in Metropolis (Ionien): Ein kurzer Bericht mit epigraphischem Anhang". Ed. B. Dreyer, Die Surveys im Hermos- und Kaystrostal und die Grabungen an den Thermen von Metropolis sowie am Stadion von Magnesia am Meander (Ionien): Oriente $\backsim$ Occident in Antiquity, Bd./Vol.1. Berlin, 107-124.

Aybek S., O. Gülbay, Y. Balım \& B. Arslan 2015, "Metropolis 2014 Yılı Çalışmaları”. KST XXXVII/3, 25-45.

Aybek S. \& Arslan B. 2015, "Metropolis'te Bulunan MS 2.-3. Yüzylla Tarihli İon Tipi Sütun Başlıkları". Eds. E. Okan \& C. Atila, Prof. Dr. Ömer Özyiğit’e Armağan. İstanbul, 29-45.

Aybek S. 2016, "Metropolis'te Bulunan Üç Roma Hamamı: Şehir Planlama, Mimari Özellikler ve Sosyal Kontekst Bakımından Kısa Bir Değerlendirme". Arkeoloji ve Sanat 153, 109-124.

Aybek S., O. Gülbay, Y. Balım \& B. Arslan 2017, "Metropolis Arkeolojik Araştırmaları, 2015". KST XXXVIII/1, 439-456.

Aybek S. 2018a, "A Brief Presentation of Hellenistic and Roman Statues from The Civic Center of Metropolis”. Eds. B. Dreyer \& S. Aybek, Orient \& Occident in Antiquity/Orient \& Okzident in der Antike. Vol. 3, 9-24.

Aybek S. 2018b, "Metropolis’ten İki Komutan-Yönetici Heykeli Parçası". Sefad 39, 293-310.

Aybek S. \& Gülbay O. 2019, "The Cult of Zeus Krezimos at Metropolis Previous Observations on the Sacred Area and Cult". Eds. B. Engels, S. Huy \& C. Steitler, Byzas 24, 241-252.

Aybek S. \& Arslan B. 2020, "Metropolis’te Bulunan Mezarlar ve Kentin Nekropolis Lokalizasyonu Üzerine Düşünceler”. Tüba-Ar 26, 111-130.

Aybek S., Arslan B., Balım, Y. \& Canseven, U. 2020, "Metroplis 2018 Yılı Çalışmaları”. KST XLI/4, 151-170.

Aybek S., B. Arslan \& O. Gülbay 2021, The Peristyle House of Metropolis. İstanbul.

Bes P. 2017, "Bearing the Stamp of Change: Epigraphic Stamps on Eastern Sigillata A and B". Neue Bilderwelten: Zur Ikonographie und Hermeneutik Italischer Sigillata, Tübinger Archäologische Forschungen 23, 241-272.

Beyll, D. 1993, "Terra Sigillata aus der Marienkirche in Ephesos Erste Zwischenbilanz". ÖAI Berichte und Materialen 5, 5-45.

Ekin-Meriç A. 2014, "A New Deposit from a 'Banquet Hall' of the Bath-Gymnasium in Metropolis". ÖAI $83,11-41$.

Ekin-Meriç A. \& Öz A. K., "Metropolis Peristilli Ev Mimarisi ve Seramik Buluntuları”. ADerg XXII, 263-278.

Eliüşük M. 2021, "Menderes Magnesiası Artemis Kutsal Alanı Güney Stoa'da Bulunan Doğu Sigillata B Grubu Seramikleri”. Arkhaia Anatolika, Anadolu Arkeolojisi Araștırma Dergisi 4, 14-40.

Erol D. 2004, Tralleis Kenti Kazılarında Ele Geçen Baskılı Terra Sigillata. Yayımlanmamış Yüksek Lisans Tezi, Adnan Menderes Üniversitesi. Aydın.

Erol D. 2007, "Smyrna Devlet Agora Buluntusu Terra Sigillataları". Eds. B. Böhlendorf-Arslan, A. O. Uysal \& J. Witte-Orr, Proceeding of the First International Symposium on Late Antique, Byzantine, Seljuk and Ottoman Pottery and Tiles in Archaeological Context, Byzas 7. Çanakkale, 1-3 June 2005, İstanbul, 73-94.

Ferrazzoli A. F. 2003, "Instrumentum Domesticum. Tipologia Dei Reperti Ceramici e Aspetti Delle Produzioni e Della Circolazione Dei Materiali”. Ed. E. Equini Schneider, Elaiussa Sebate II: Un Porto tra 
Oriente e Occidente, Roma: L'ERMA di Bretschneider. Roma, 649-661.

Gassner V. 1997, Das Südtor der Tetragonos Agora, Keramik und Kleinfunde (FIE 13, 1,1). Wien.

Güngör E. 2005, Metropolis Kenti Ada 7 İçerisindeki Konut Seramiği. Yayımlanmamış Yüksek Lisans Tezi, Dokuz Eylül Üniversitesi. İzmir.

Hayes J. W. 1972, Late Roman Pottery. London.

Hayes J. W. 1973, "Roman Pottery from the South Stoa and Corinth”. Hesperia 42, 416-470.

Hayes J. W. 1985, "Sigillate Orientali". EAA, Enciclopedia dell'Arte Classica e Orientale. Atlante delle Forme

Ceramiche II: Ceramica Fine Romana nel Bacino Mediterraneo. Roma.

Hayes J. W. 1991, Paphos. The Hellenistic and Roman Pottery (Paphos Bd. III). Nicosia.

Hayes J. W. 2008, The Roman Pottery. Fine Ware Imports (The Athenian Agora XXXII). Princeton.

Heberdey R. 1906, "Kleinfunde”. Ed. O. Benndorf, Forschungen Ephesos FIE I. Wien, 167-180.

Hellström P. 1965, Labraunda II.1: Pottery of Classical and Later Date, Terracotta Lamps and Glass

(Swedish Excavations and Researches). Lund.

Iliffe J. H. 1936, "Sigillata Wares in the Near East a list of Potters' Stamps". QDAP 6, 4-53.

Jones F. F. 1950, “The Pottery”. Ed. H. Goldman, Excavations at Gözlükule, Tarsus I: The Hellenistic and Roman Periods. Princeton, 149-296.

Kenrick P. M. 1985, "The Fine Pottery". Excavations at Sidi Khrebish Benghazi (Berenice), Vol. III, Part 1, Supplements to Libya Antiqua- $V$. London.

Kenyon K. M. 1957, "Roman and Later Wares, Terra Sigillata". Eds. J. W. Crowfoot, G. M. Crowfoot \& K. M. Kenyon, The Objects from Samaria, Samaria - Sebaste, Reports of the Work of the Joint Expedition in 1931-1933 and of the British expedition in 1935 Band 3. London, 281-306.

Korkut T. \& Işın G. 2015, "Fethiye Müzesi'nden Bir Grup Tlos Seramiği". Ed. T. Korkut, Arkeoloji, Epigrafi, Jeoloji, Doğal ve Kültürel Peyzaj Yapısıyla Tlos Antik Kenti ve Teritoryumu. Ankara, 213- 227.

Ladstatter S. 2000, "Ein flavischer Fundkomplex aus dem Hanghaus 2 von Ephesos". RCRF Acta 36, 97-104.

Ladstatter S. 2005, "Keramik”. Ed. H. Tür, Hanghaus 2 in Ephesos. FIE 8.6. Wien, 230-358.

Ladstatter S. 2008, “Terra Sigillata aus den Planierschichten des Vediusgymnasiums”. Eds. M. Steskal \& M. La Torre, Das Vediusgymnasium in Ephesos, FiE XIV/1. Wien, 97-110.

Ladstatter S. 2010, "Keramik". Ed. A. Hofeneder, Hanghaus 2 in Ephesos. FIE 8.8. Wien, 172-279.

Ladstatter S. \& H. Liedl 2020, "Die Gefäßkeramik”. Ed. S. Ladstätter, Eine Frühkaiserzeitliche Grubenverfüllung aus dem Hanghaus 2 in Ephesos, Ergänzungshefte zu den Jahresheften des Österreichischen Archäologischen Institutes 18. Wien, 21-99.

Lund 2003, "Eastern Sigillata B: A Ceramic Fine Ware Industry in the Political and Commercial Landscape of the Eastern Mediterranean”. Ed. C. Abadie-Reynal, Les Ceramiques en Anatolie aux Epeques Hellenistique et Romaine, Actes de la Table Ronde d'Istanbul, 23-24 mai 1996. İstanbul, 125-136.

Lund J. 2016, "Eastern Sigillata A Ware: the Riddle of the Stamps". Eds. M. Giannopoulou \& C. Kallini, Festschrift for Stella Drougou, vol. I. 830-840.

Meriç R. 2002, Spathellenistisch-römische Keramik und Kleifunde aus einem Schachtbrunnen am Staatsmarkt in Ephesos (Forschungen in Ephesos IX/3). Wien.

Meriç R., Öz A. K. \& Ekin-Meriç A. 2005, "2003 Metropolis Kazıları”. KST XXVI/2, 137-147.

Meriç R., A. K. Öz, A. Ekin-Meriç \& S. Aybek 2006, "Metropolis 2004 Yılı Kazı Çalışmaları". KST XXVII/1, 249-261.

Meriç R., A. K. Öz, A. Ekin-Meriç, S. Aybek, \& E. Güngör 2007, "2005 Yılı Metropolis Kazıları”. KST XXVIII/2, 243-253.

Mitsopoulos-Leon V. 1991, Die Basilika am Staatsmarkt in Ephesos Kleifunde, 1. Teil: Keramik Hellenistischer und Römischer Zeit (FIE IX 2/2). Schindler-Wien.

Munsell 2013, Munsell Soil Color Charts. Washington D.C.

Özdilek B. 2018, “Andriake Limanı’ndan Tralleis Üretimi Doğu Sigillata B Grubu Seramikleri”. Eds. M. 
Arslan \& F. Baz, Arkeoloji, Tarih ve Epigrafinin Arasında: Prof. Dr. Vedat Çelgin’in 68. Doğum Günü Onuruna Makaleler. İstanbul, 635-658.

JPoblome J. 1999, "Sagalassos Red Slip Ware: Typology and Chronology". Ed. M. Waelkens, Studies in Eastern Mediterranean Archaeology II. Brepols.

Robinson H. S. 1959, Pottery of the Roman Period, The Athenian Agora V. Princeton, New Jersey.

Sackett L. H. 1992, Roman Pottery. Knossos from Greek City to Roman Colony. Excavations at the Unexplored Mansion II (BSA. Suppl. 21). London.

Slane K. W. 1990, The Sanctuary of Demeter and Kore: The Roman Pottery and Lamps (Corinth XVIII Bd.2). New Jersey.

Şimşek C., M. Okunak \& M. Bilgin 2011, Laodikeia Nekropolü (2004-2014 Yilları) 1.1. İstanbul.

Takaoğlu T. 2006, "New Lights on the Origins of Eastern Sigillata B Ware". Ed. T. Takaoğlu, Anadolu Arkeolojisine Katkılar, 65. Yaşında Abdullah Yaylali'ya Sunulan Yazılar. İstanbul, 263-267.

Tekocak M. 2019, "Stratonikeia Kazılarında Bulunan Kırmızı Astarlı Seramikler”. Ed. B. Söğüt, Stratonikeia Çalışmaları 4. Mimari, Heykel ve Küçük Buluntu Araştırmaları. İstanbul, 85-123.

Unterkircher E. 1983, “Terra Sigillata aus dem Heraion von Samos”. AM 98, 173-214.

Uygun Ç 2011, Tepecik Kırmızı Astarlı Seramikleri (İ.Ö.2. YY - İ.S. 4. YY) (Patara IV, 2). İstanbul.

Waagé F. O. 1933, "Excavations in the Athenian Agora, The Roman And Byzantine Pottery". Hesperia 2, 279-328.

Waagé F. O. 1948, Antioch on-the-Orontes IV, 1, Ceramics and Islamic Coins. Princeton.

Williams C. 1989, Anemurium, The Roman and Early Byzantine Pottery. Wetteren.

Wintermeyer U. 2004, Die Hellenistische und fruhkaiserzeitliche Gebrauchskeramik, Auf Grundlage der Stratifierten Fundkeramik aus dem Bereich der heiligen Strasse (Didyma III.2). Mainz.

Vapur Ö. 2001, Magnesia ad Maeandrum Gymnasionu Roma Dönemi Seramikleri. Yayımlanmamış Yüksek Lisans Tezi, Ankara Üniversitesi. Ankara.

Vapur Ö. 2011, "Menderes Magnesiası Theatron Kazısı Seramik Buluntuları". Anadolu/Anatolia 37, 143-193.

Vapur Ö. 2013, "Menderes Magnesiası Hypokaustlu Yapı Kazılarında Ele Geçen İthal Kaliteli Seramikler". Ed. G. Kökdemir, Orhan Bingöl 67. Yaş Armağanı. Ankara, 641-666.

Yıldız V. 2016, “Akhisar Arkeoloji Müzesi’nde Bulunan Bir Grup Roma Seramiği”. Manisa Celal Bayar Üniversitesi Sosyal Bilimler Dergisi 14/3, 252-273.

Yıldız V. 2019a, "Alanya Arkeoloji Müzesi’nde Bulunan Doğu Sigillataları A, B ve C Grubu Seramikleri”. Dicle Üniversitesi Sosyal Bilimler Enstitüsü Dergisi (DÜSBED) 23, 108-127.

Yıldız V. 2019b, "Soli Pompeiopolis Sütunlu Caddesi’nde Bulunan Doğu Sigillatası D Grubu Seramikleri”. Selçuk Üniversitesi Edebiyat Fakültesi Dergisi (SEFAD) 42, 245-274.

Zelle M. 1997, Die Terra Sigillata aus der Westtor- Nekropole in Assos (Asia Minor Studien, Bd. 27). Bonn.

Zoroğlu L. 1986, "Samsat'da Bulunan Doğu Sigillataları İlk Rapor”. Selçuk Üniversitesi Edebiyat Fakültesi Dergisi (SEFAD) 3, 61-100. 